\title{
Quantum Chemical and Spectroscopic Investigations of (Ethyl 4 hydroxy-3-((E)-(pyren-1-ylimino)methyl)benzoate) by DFT Method
}

\author{
Diwaker and Abhishek Kumar Gupta \\ School of Basic Sciences, Indian Institute of Technology Mandi, Mandi, Himachal Pradesh-175001, India \\ Correspondence should be addressed to Diwaker; diwakerphysics@gmail.com
}

Received 17 February 2014; Revised 2 April 2014; Accepted 5 April 2014; Published 9 July 2014

Academic Editor: Hakan Arslan

Copyright (C) 2014 Diwaker and A. K. Gupta. This is an open access article distributed under the Creative Commons Attribution License, which permits unrestricted use, distribution, and reproduction in any medium, provided the original work is properly cited.

In the present work we have reported the optimized ground state geometry, harmonic vibrational frequencies, NMR chemical shifts, NBO analysis, and molecular electrostatic potential surface map of the title compound using DFT/B3LYP/6-311++G(2d, 2p) level of theory. We have compared our calculated results with the experimentally obtained values and found that both are in close agreement with each other. We have used the gauge-invariant atomic orbital (GIAO) approach to calculate the NMR $\left({ }^{13} \mathrm{C}\right.$ and $\left.{ }^{1} \mathrm{H}\right)$ chemical shifts using Gaussian 09 package. TD-DFT (time-dependent DFT) approach has been used to simulate the electronic spectra of the title compound in order to account for excited states. Other molecular properties such as HOMO-LUMO energies, NBO analysis, and PED distribution analysis have been studied and reported using DFT/B3LYP/6-311++G(2d, 2p) level of theory.

\section{Introduction}

The title compound chosen for DFT studies to extract different molecular properties has been experimentally synthesized and prepared using 1 amino pyrene and (ethyl 3-formyl4-hydroxybenzoate) at room temperature for six hours in the presence of dry $\mathrm{MeOH}[1]$. The title compound shows sensing properties for selective detection of niobium ions in mixed aqueous media. In the literature survey we found that there are lot of research articles based upon fluorescent techniques for detection of various metal ions, however literature survey also reveals very few ab initio HF/MP2/DFT calculations of such type of compounds. Fluorescence is a very simple technique and acts as a convenient characterization tool for detection of very small amount (in ppm) of various metal ions in solutions [2]. From application point of view niobium metal is used in various kinds of applications such as superconducting magnets [3] and biological applications [4]. In interest of such applications the quantum mechanical calculations of the title compound are thoroughly investigated. The aim of this work is to predict the structural, electronic, vibrational, and spectral parameters and other molecular properties of the title compound using DFT approach [5-9].

\section{Experimental Details}

In this section we have reported short details about the methodology and characterization tools used for the title compound, however we advised the readers to consult [1] for more details. The chemical structure and fluorescent properties of the title compound are confirmed by single crystal X-ray diffraction, UV spectra, ${ }^{1} \mathrm{H}$ and ${ }^{13} \mathrm{C}$ NMR, and FTIR spectra. ${ }^{1} \mathrm{H}$ and ${ }^{13} \mathrm{C}$ NMR are recorded in chloroform using TMS as internal standard on a Varian Mercury 300 spectrometer operating at $300 \mathrm{MHz}$ for ${ }^{1} \mathrm{H}$ and $75 \mathrm{MHz}$ for ${ }^{13} \mathrm{C}$. IR spectra are recorded on a Perkin-Elmer PE983 infrared spectrometer as $\mathrm{KBr}$ pellets with absorption reported in $\mathrm{cm}^{-1}$. The ultraviolet absorption spectra were recorded on Shimadzu UV-2450 spectrophotometer. Fluorescent spectra measurements were performed on Agilent Technologies Cary Eclipse fluorescence spectrometer. 


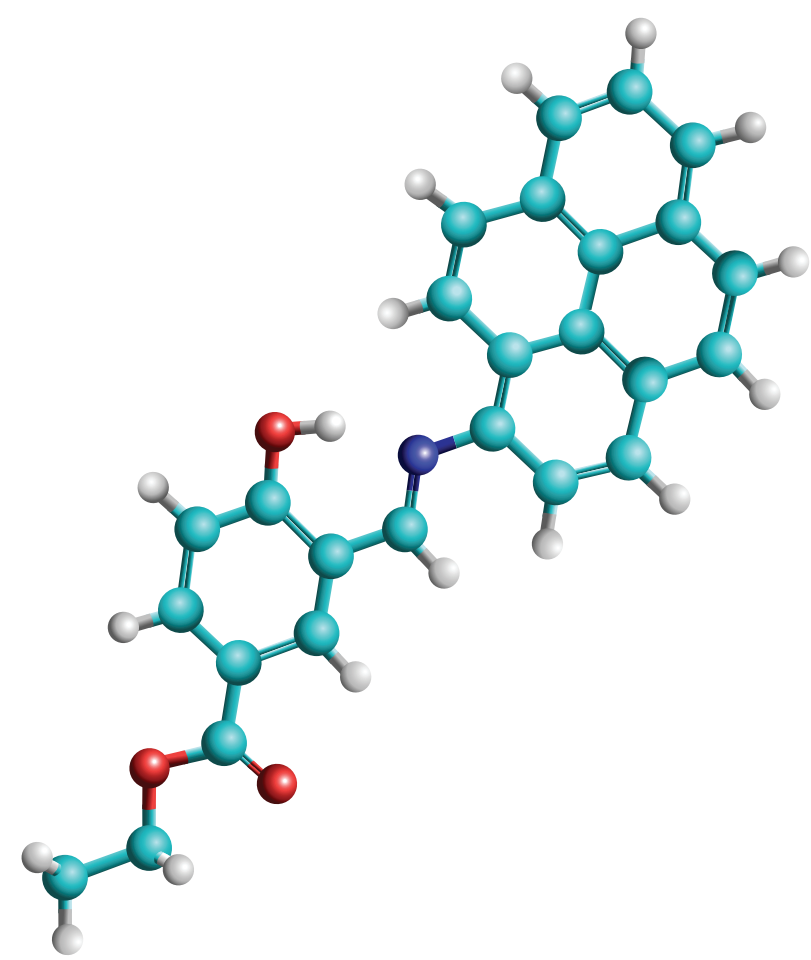

FIGURE 1: Structure of new Schiff base ((ethyl 4 hydroxy-3-((E)-(pyren-1-ylimino)methyl)benzoate) using hyperchem.

\section{Computational Details}

Using DFT/B3LYP/6-311++G(2d, 2p) level of theory [10] we have investigated the ground state optimized geometry of the title compound. The molecular geometry is fully optimized using tight convergence criteria along with redundant internal coordinates and Berny's optimization algorithm. The optimized parameters obtained using DFT approach have been compared with the experimental values and are in close agreement with them. Further we have used the optimized ground state geometry of the title compound to study the different properties like NMR spectra, UV-Vis spectra, MEP surface mapping, PED analysis, and NBO analysis. Using DFT/B3LYP/6-311++G(2d, 2p) level of theory and GAIO (Gauge-Invariant Atomic Orbital) [11, 12] approach we have reported the NMR $\left({ }^{13} \mathrm{C}\right.$ and $\left.{ }^{1} \mathrm{H}\right)$ chemical shifts of the title compound and compared them with their experimental counterparts. To study the electronic transitions and excited states we have used the TD-DFT (time-dependent) method available in Gaussian 09 package. HOMO-LUMO energies are also calculated at DFT/B3LYP/6-311++G(2d, 2p) level of theory. Vibrational wavenumbers assignment is done by using VEDA 4 program. MEP surface mapping is investigated to comment upon the reactive nature of the title compound. In order to find out the various interactions between the filled and the vacant orbitals, NBO analysis [13] of the title compound has been done using $\mathrm{NBO} 3.1$ program available in Gaussian 09 package at DFT/6-311++G(2d, 2p) level of theory. The unoptimized structure of our title compound is presented in Figure 1.

\section{Results and Discussion}

4.1. Molecular Geometry. We have used the DFT/B3LYP/6$311++\mathrm{G}(2 \mathrm{~d}, 2 \mathrm{p})$ level of theory available in Gaussian 09 program to investigate the ground state geometry of the title compound. The geometry is fully optimized with tight convergence criteria and the structure is local minima on the PES. On comparison with the experimentally obtained parameters one can conclude that our calculation is successful, as the difference between calculated and experimental bond lengths, bond angles is of few $\AA$. Figure 2 represents the stable conformation of the title compound using DFT calculations. The selected calculated bond lengths $(R)$ and angles $(\AA)$ for the title compound along with their corresponding experimental values are listed in Table 1.

Correlation between [14] the calculated and the experimental parameters of bond lengths and bond parameters for the title compound are shown in Figure 3. Bond length and bond angles correlation $R^{2}$ values are 0.9802 and 0.9921 , respectively.

4.2. Chemical Shifts. NMR spectroscopy is considered as a valuable tool for the structural and functional characterization of molecules. ${ }^{1} \mathrm{H}$ and ${ }^{13} \mathrm{C}$ NMR chemical shifts of the title compound are investigated using DFT/B3LYP/6-311++G(2d, $2 \mathrm{p}$ ) level of theory with GIAO (gauge-invariant atomic orbital) approach in DMSO. The calculated ${ }^{1} \mathrm{H}$ and ${ }^{13} \mathrm{C}$ NMR chemical shifts of the title compound together with the corresponding experimental values are shown in Tables 2 and 


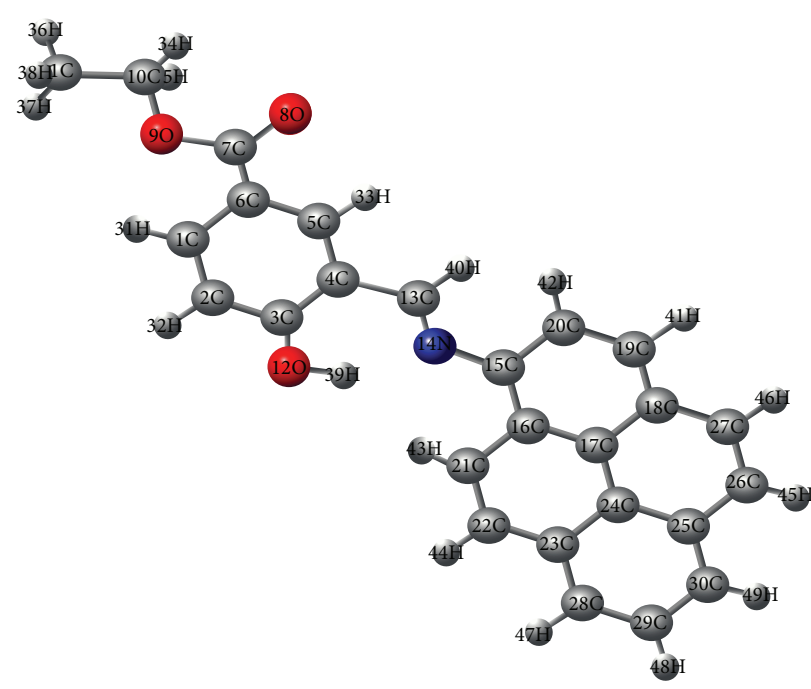

FIGURE 2: Stable structure of new Schiff base using DFT approach with energy $=-1282.65751536$ au.

TABLE 1: The selected calculated and experimental values [1] ${ }^{*}$ for the stable conformation of the title compound.

\begin{tabular}{lccc}
\hline \multicolumn{3}{l}{ Serial number $R$ (bond length/angstrom) } & \multicolumn{3}{c}{ Calculated } & Experimental \\
\hline 1 & $R(3,12)$ & 1.36 & 1.35 \\
2 & $R(7,8)$ & 1.24 & 1.23 \\
3 & $R(13,14)$ & 1.30 & 1.29 \\
4 & $R(9,7)$ & 1.37 & 1.34 \\
5 & $R(9,10)$ & 1.48 & 1.45 \\
6 & $R(14,15)$ & 1.41 & 1.41 \\
\hline Serial number & $A($ angle/degrees) & Calculated & Experimental \\
\hline 1 & $A(13-14-15)$ & 121.30 & 120.98 \\
2 & $A(12-3-4)$ & 121.10 & 120.37 \\
3 & $A(8-7-6)$ & 124.98 & 124.94 \\
4 & $A(9-10-11)$ & 106.83 & 106.84 \\
5 & $A(7-9-10)$ & 117.12 & 117.78 \\
6 & $A(12-3-2)$ & 118.82 & 118.86 \\
7 & $A(8-7-9)$ & 122.09 & 123.01 \\
8 & $A(9-7-6)$ & 112.92 & 112.95 \\
\hline
\end{tabular}

$R$ : Bond lengths (in Angstrom); A: Angles (in Degrees).

3 as values relative to tetramethylsilane. The ${ }^{1} \mathrm{H}$ NMR spectra of the title compound in DMSO show a triplet peak in the range from 1.36 to $1.40 \mathrm{ppm}$ for $\mathrm{C}-\mathrm{CH}_{3}$ and quartet peak in the range from 4.32 to $4.38 \mathrm{ppm}$ for $\mathrm{O}-\mathrm{CH}_{2}$. Corresponding calculated values are in the range from 1.31 to $1.46 \mathrm{ppm}$ and 4.27 to $4.32 \mathrm{ppm}$, respectively. Aromatic protons in pyrene appeared in the range from 8.04 to $8.48 \mathrm{ppm}$ with calculated values ranging from 8.32 to $9.03 \mathrm{ppm}$. Aromatic protons in substituted benzene showed a singlet peak at $8.66 \mathrm{ppm}$ and doublet at $8.50 \mathrm{ppm}$ and $7.16 \mathrm{ppm}$. Corresponding calculated values are $8.66 \mathrm{ppm}, 8.50 \mathrm{ppm}$, and $7.44 \mathrm{ppm}$, respectively. Proton of Schiff base shows a singlet peak at $9.37 \mathrm{ppm}$ while calculated value is at $9.34 \mathrm{ppm}$. The ${ }^{13} \mathrm{C}$ NMR spectra of the title compound in DMSO showed a peak at $14.44 \mathrm{ppm}$ for $\mathrm{C}-\mathrm{CH}_{3}$ (calculated value as $13.48 \mathrm{ppm}$ ), at $60.99 \mathrm{ppm}$ for
$\mathrm{O}-\mathrm{CH}_{2}$ (calculated value as $60.56 \mathrm{ppm}$ ), at $165.88 \mathrm{ppm}$ for $\mathrm{C}=\mathrm{O}$ (calculated value as $180.00 \mathrm{ppm}$ ), and at $162.81 \mathrm{ppm}$ for $\mathrm{C}=\mathrm{N}$ (calculated value as $169.94 \mathrm{ppm}$ ). Aromatic carbons of pyrene and substituted benzene showed peaks in the range from 115.67 to $165.12 \mathrm{ppm}$ while calculated values are in the range from 121.53 to $175.80 \mathrm{ppm}$. We have also reported the hydrogen and carbon NMR chemical shifts by IGAIM and CGST methods using B3LYP/6-311++G(2d, 2p) basis sets [15]. From the comparison table we can conclude that theoretical values for carbon and hydrogen NMR chemical shifts calculated by GIAO method are in close agreement as compared to other CGCST and IGAIM methods. Linear correlation coefficients $\left(R^{2}\right)$ for linear regression analysis of theoretical and experimental values of ${ }^{1} \mathrm{H}$ and ${ }^{13} \mathrm{CNMR}$ chemical shifts using GIAO method are found to be 0.9959 and 0.9958 respectively.

4.3. Frontier Molecular Orbitals. Analysis of the HOMOLUMO band gap helps us in understanding many molecular properties of a molecule like chemical reactivity, UV-Vis spectra, and stability of the molecule [16] along with optical and electrical properties. Chemical reactivity of a molecule can be determined from the HOMO-LUMO band gap. A small band gap implies low kinetic stability of the molecule. HOMO-LUMO separation is a result of significant degree of intermolecular charge transfer from the electron donor groups to the electron acceptor groups through $\pi$ conjugated paths. Energy gap between HOMO and LUMO has also been used to prove the bioactivity from intramolecular charge transfer (ICT). We have reported the HOMO-LUMO analysis of the title compound using DFT/B3LYP/6-311++G(2d, $2 p)$ level of theory [17]. In our analysis we found that the title compound has a total of 986 orbitals out of which 103 are occupied and the remaining 883 are virtual orbitals. The orbitals numbered as 103 and 104 account for HOMO and LUMO orbitals. The HOMO-LUMO energies of the title compound have also been calculated using ab initio calculations and are found to be -5.63 electron volts and -2.50 


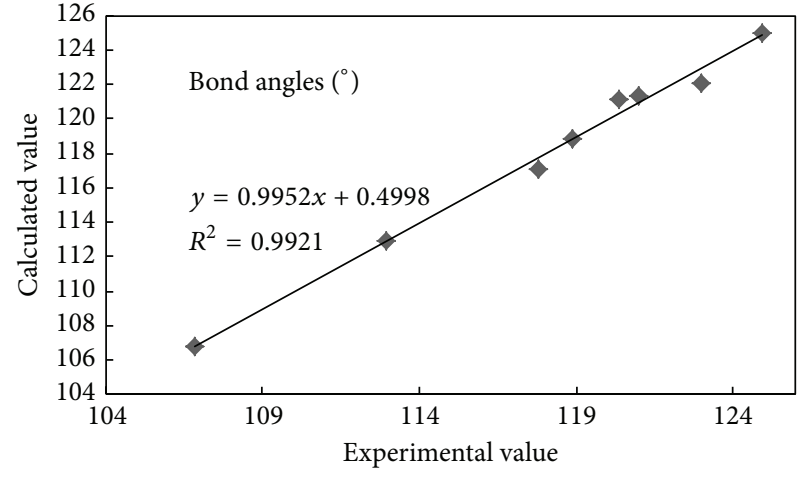

(a)

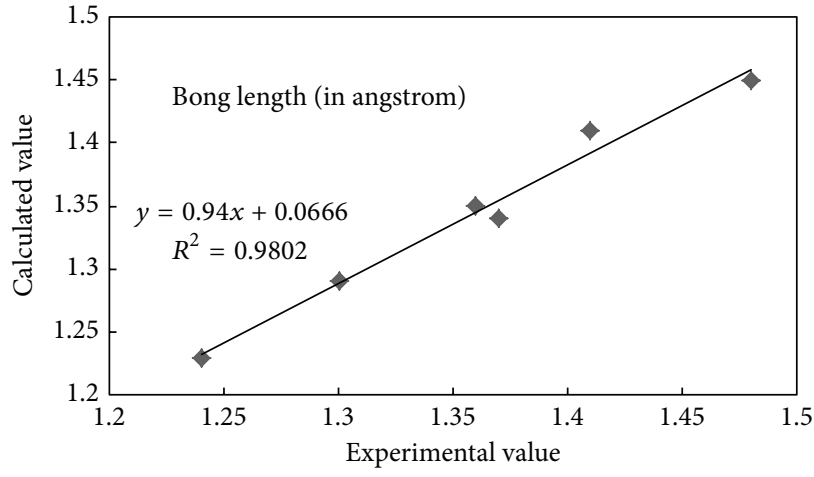

(b)

FIgURE 3: Correlation between the calculated and the experimental values of the (a) bond angles and (b) bond length for the stable conformation of the title compound.

TABLE 2: Comparison of DFT/B3LYP/6-311++G (2d, 2p) calculated and experimental values $[1]^{*}$ of ${ }^{1} \mathrm{H}$ chemical shift (ppm) relative to the TMS for the title compound.

\begin{tabular}{|c|c|c|c|c|c|}
\hline Atom & Experimental value & & $\begin{array}{c}6311++\mathrm{G} \\
(2 \mathrm{~d}, 2 \mathrm{p}) / \mathrm{GIAO}\end{array}$ & $\begin{array}{c}6311++\mathrm{G} \\
(2 \mathrm{~d}, 2 \mathrm{p}) / \mathrm{CGCST}\end{array}$ & $\begin{array}{c}6-311++\mathrm{G} \\
(2 \mathrm{~d}, 2 \mathrm{p}) / \mathrm{IGAIM}\end{array}$ \\
\hline H39 & 14.15 & $(\mathrm{~s}, 1 \mathrm{H}, \mathrm{ArOH})$ & 15.22 & 15.69 & 15.68 \\
\hline $\mathrm{H} 40$ & 9.37 & $(\mathrm{~s}, 1 \mathrm{H}, \mathrm{N}=\mathrm{CH})$ & 9.34 & 9.56 & 9.56 \\
\hline \multicolumn{6}{|l|}{ H41, H42, H43, H44 } \\
\hline $\mathrm{H} 45, \mathrm{H} 46, \mathrm{H} 47, \mathrm{H} 48$ & $8.04-8.48$ & (9H, Ar CH, Pyrene) & $8.32-9.03$ & $8.46-9.46$ & $8.45-9.46$ \\
\hline \multicolumn{6}{|l|}{$\mathrm{H} 49$} \\
\hline $\mathrm{H} 31$ & 8.50 & $(\mathrm{~d}, 1 \mathrm{H}, \mathrm{ArCH})$ & 8.50 & 8.77 & 8.77 \\
\hline $\mathrm{H} 32$ & 7.16 & $(\mathrm{~d}, 1 \mathrm{H}, \mathrm{Ar} \mathrm{CH})$ & 7.34 & 7.70 & 7.70 \\
\hline H33 & 8.66 & $(\mathrm{~s}, 1 \mathrm{H}, \mathrm{Ar} \mathrm{CH})$ & 8.66 & 8.99 & 8.99 \\
\hline H34, H35 & $4.32-4.38$ & $\left(\mathrm{~s}, 2 \mathrm{H}, \mathrm{O}-\mathrm{CH}_{2}\right)$ & $4.27-4.32$ & $4.75-4.82$ & $4.74-4.81$ \\
\hline H36, H37, H38 & $1.36-1.40$ & $\left(\mathrm{~T}, 3 \mathrm{H}, \mathrm{C}-\mathrm{CH}_{3}\right)$ & $1.31-1.46$ & $1.60-1.89$ & $1.60-1.89$ \\
\hline
\end{tabular}

electron volts, respectively. The HOMO-LUMO for the title compound has been shown in Figure 4 and the gap is found to be 3.13 electron volts. The HOMO LUMO distribution is mostly localized on the rings which show that they are $\pi$ type orbitals. HOMO (103) $\rightarrow$ LUMO (104) transition implies an ED transfer between rings $\left(\pi \rightarrow \pi^{*}\right)$ transition. From this value of band gap we can predict that the title compound can be used for organic solar cell applications, title compound has high kinetic susceptibility and low chemical reactivity. Using HOMO and LUMO energies along with equations as $\varepsilon=(I+A) / 2$ which is electronegativity, $\beta=(I-A) / 2$ as chemical hardness with $\delta=1 / 2 \beta$ as chemical softness has been calculated for the title compound. The terms $I$ and $A$ are equivalent to $I=-E_{\mathrm{HOMO}}$ and $A=-E_{\mathrm{LUMO}}$ and are referred to as ionization potential and electron affinity, respectively. In addition to HOMO/LUMO energies the HOMO-1/LUMO+1 energies of the title compound have been calculated using B3LYP/6-311++G(2d, 2p) level of theory and are found to be $-5.61 \mathrm{eV}$ and $-2.41 \mathrm{eV}$, respectively. Electron donating and electron withdrawing ability of the title compound are expresses in terms of $\varepsilon, \beta$, and $\delta$ and come out to be 4.065 , 1.565 , and 0.3194 [18].
4.4. MEP Surface Mapping. We have reported and plotted the MEP surface mapping, alpha density, and total density of the title compound using Gaussian 09 program. The molecular electrostatic potential surface along with Alpha density and total density for the title compound is represented in Figure 5.

MEP surface mapping is useful in understanding hydrogen bonding interactions as well as sites for electrophilic and nucleophilic attacks $[19,20]$. The MEP surface provides us with net electrostatic effect caused due to total charge distribution. It can be considered as a fruitful quantity to understand the various molecular properties like hydrogen bonding and reactivity. It also provides a useful tool to know the relative polarity of the molecule [21]. Portion of the molecule which has -ve electrostatic potential will be susceptible to electrophilic attack. The surface is color coded as per the electrostatic potential (red is more electron rich area and blue is more electron poor area.). The total electron density plot of the title compound shows a uniform distribution. The order in the increase of the electrostatic potential as per color code will follow as red $<$ orange $<$ yellow $<$ green $<$ blue [22]. At last we conclude that the 
TABLE 3: Comparison of B3LYP/6-311++G(2d, 2p) calculated and experimental values $[1]^{*}$ of ${ }^{13} \mathrm{C}$ chemical shift (ppm) relative to the TMS for the title compound.

\begin{tabular}{|c|c|c|c|c|c|}
\hline Atom & Experimental & & $\begin{array}{c}6-311++\mathrm{G} \\
(2 \mathrm{~d}, 2 \mathrm{p}) / \mathrm{GIAO}\end{array}$ & $\begin{array}{c}6-311++\mathrm{G} \\
(2 \mathrm{~d}, 2 \mathrm{p}) / \mathrm{CGST}\end{array}$ & $\begin{array}{c}6-311++\mathrm{G} \\
(2 \mathrm{~d}, 2 \mathrm{p}) / \mathrm{IGAIM}\end{array}$ \\
\hline $\mathrm{C} 15-\mathrm{C} 30$ & $117.52-141.50$ & (16C, Ar C, pyrene) & $115.60-148.50$ & $118.77-167.66$ & $118.76-167.66$ \\
\hline $\mathrm{C} 1-\mathrm{C} 6$ & $115.67-165.12$ & (6C, Ar C, substituted benzene) & $121.53-175.80$ & $120.60-176.80$ & $120.59-176.80$ \\
\hline $\mathrm{C} 7$ & 165.88 & $(1 \mathrm{C}, \mathrm{Ar} \mathrm{C}=\mathrm{O})$ & 180.00 & 179.0 & 179.07 \\
\hline $\mathrm{C} 13$ & 162.81 & $(1 \mathrm{C}, \mathrm{Ar} C=\mathrm{N})$ & 169.94 & 167.66 & 167.66 \\
\hline $\mathrm{C} 10$ & 60.98 & $\left(1 \mathrm{C}, \mathrm{OCH}_{2}\right)$ & 60.56 & 68.66 & 68.66 \\
\hline C11 & 14.44 & $\left(1 \mathrm{C}, \mathrm{CH}_{3}\right)$ & 13.48 & 13.51 & 13.50 \\
\hline
\end{tabular}

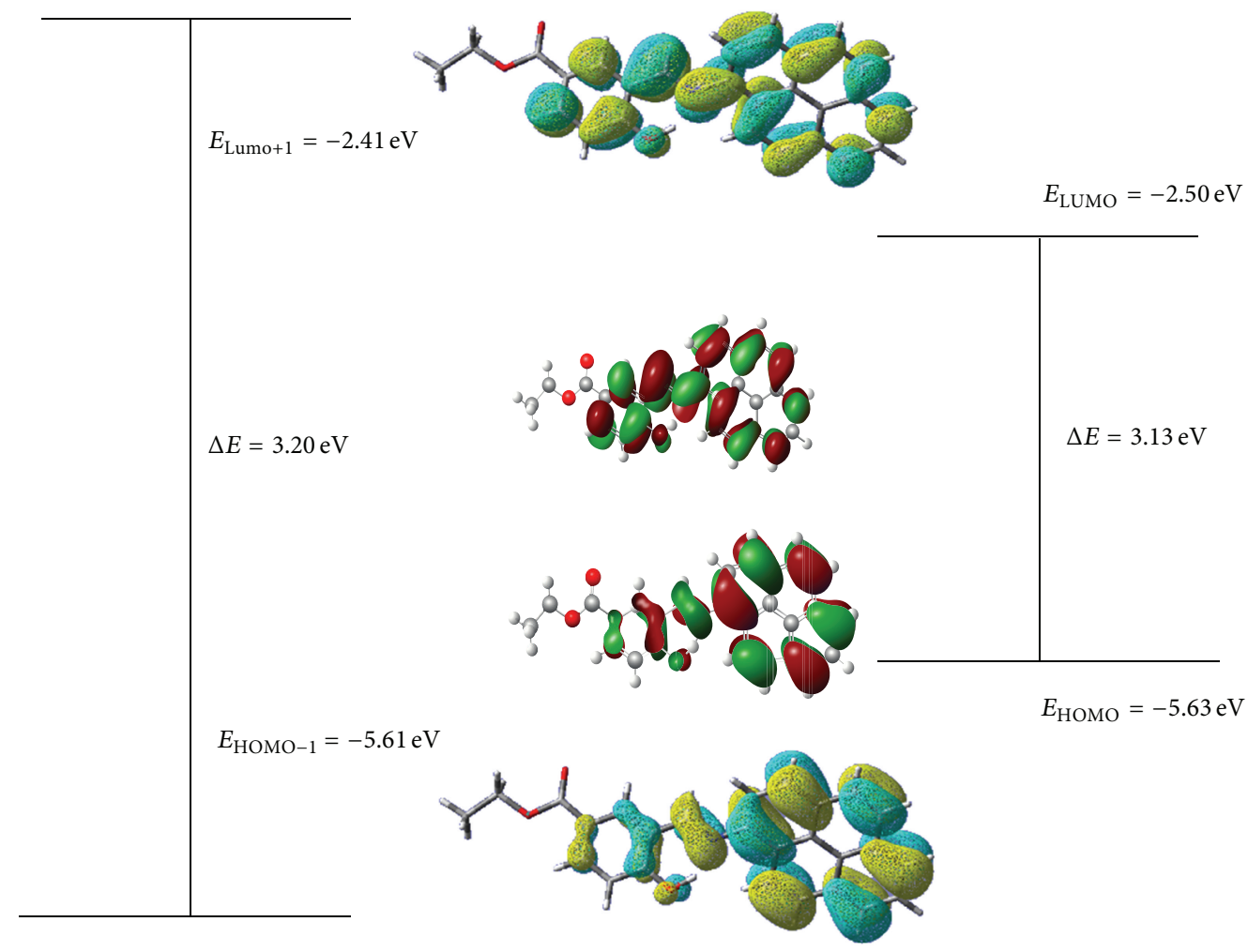

FIgURE 4: HOMO/LUMO and HOMO-1/LUMO+1 energies of the title compound calculated at B3LYP level of theory using 6-311++G(2d, 2 p) basis set.

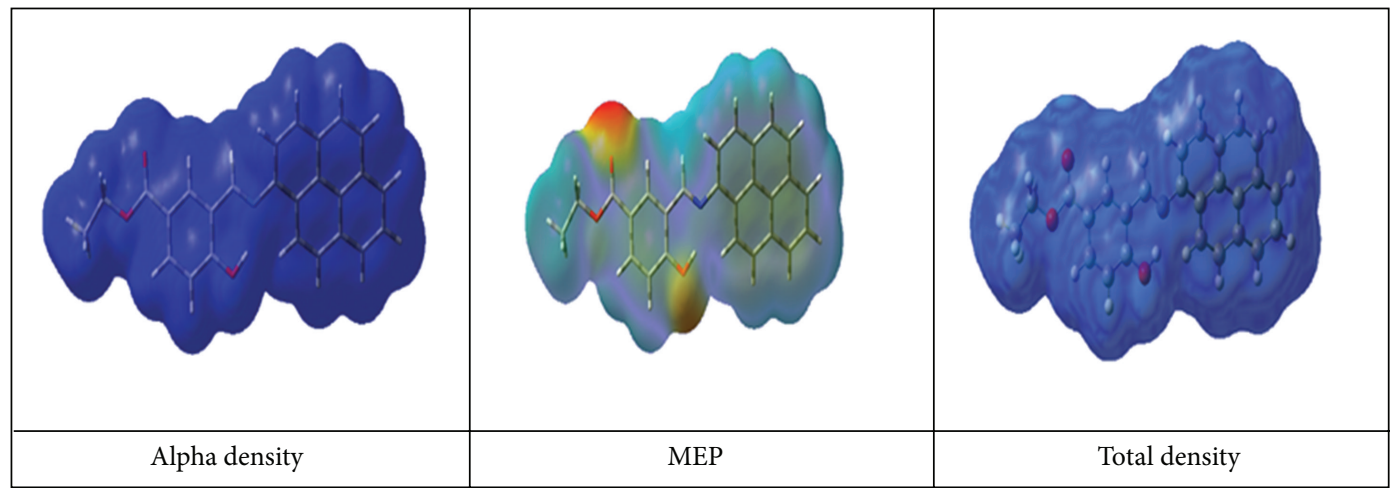

FIGURE 5: MEP, alpha density, and total density of the title compound using Gaussian 09 package. 
TABLE 4: Calculated electronic absorption spectrum of (ethyl 4 hydroxy-3-((E)-(pyren-1-ylimino) methyl) benzoate) using TD DFT/B3LYP/6$311++\mathrm{G}(2 \mathrm{~d}, 2 \mathrm{p})$, with experimentally reported values by other authors in brackets.

\begin{tabular}{|c|c|c|c|c|}
\hline Excited state (triplet/singlet) & CI expansion coefficient & Energy $(\mathrm{eV})$ & Wavelength calc. (nm) & Oscillator Strength (f) \\
\hline $1(\mathrm{~T})$ & 0.64282 & \multirow{3}{*}{1.8590} & \multirow{3}{*}{666.95} & \multirow{3}{*}{0.0000} \\
\hline $103 \rightarrow 104$ & -0.20390 & & & \\
\hline $103 \rightarrow 105$ & -0.11486 & & & \\
\hline \multicolumn{5}{|l|}{$103 \rightarrow 106$} \\
\hline $2(\mathrm{~T})$ & 0.14567 & \multirow{9}{*}{2.6252} & \multirow{9}{*}{472.28} & \multirow{9}{*}{0.0000} \\
\hline $99 \rightarrow 104$ & -0.13249 & & & \\
\hline $100 \rightarrow 104$ & -0.14414 & & & \\
\hline $101 \rightarrow 104$ & -0.10275 & & & \\
\hline $101 \rightarrow 105$ & -0.24936 & & & \\
\hline $102 \rightarrow 104$ & 0.17216 & & & \\
\hline $103 \rightarrow 104$ & 0.46822 & & & \\
\hline $103 \rightarrow 105$ & -0.28107 & & & \\
\hline $103 \rightarrow 106$ & 0.69539 & & & \\
\hline $3(\mathrm{~S})$ & 0.69539 & \multirow{2}{*}{2.7450} & \multirow{2}{*}{451.67} & \multirow{2}{*}{0.7677} \\
\hline $103 \rightarrow 104$ & & & & \\
\hline $4(\mathrm{~T})$ & 0.13579 & \multirow{10}{*}{3.1085} & \multirow{10}{*}{398.86} & \multirow{9}{*}{0.0000} \\
\hline $98 \rightarrow 104$ & 0.37034 & & & \\
\hline $101 \rightarrow 104$ & 0.24413 & & & \\
\hline $101 \rightarrow 105$ & 0.26932 & & & \\
\hline $102 \rightarrow 104$ & 0.17397 & & & \\
\hline $102 \rightarrow 105$ & 0.13812 & & & \\
\hline $103 \rightarrow 104$ & 0.12732 & & & \\
\hline $103 \rightarrow 105$ & -0.30215 & & & \\
\hline $103 \rightarrow 106$ & -0.15823 & & & \\
\hline \multicolumn{3}{|l|}{$103 \rightarrow 107$} & & \\
\hline $5(\mathrm{~T})$ & -0.25829 & \multirow{6}{*}{3.2510} & \multirow{6}{*}{$381.37(383)$} & \multirow{5}{*}{0.0000} \\
\hline $101 \rightarrow 104$ & 0.54783 & & & \\
\hline $102 \rightarrow 104$ & -0.16061 & & & \\
\hline $102 \rightarrow 105$ & 0.17231 & & & \\
\hline $103 \rightarrow 105$ & 0.18500 & & & \\
\hline \multicolumn{3}{|l|}{$103 \rightarrow 107$} & & \\
\hline $6(\mathrm{~T})$ & 0.12403 & \multirow{6}{*}{3.3508} & \multirow{6}{*}{370.01} & \multirow{5}{*}{0.0000} \\
\hline $99 \rightarrow 104$ & -0.18914 & & & \\
\hline $100 \rightarrow 104$ & 0.23302 & & & \\
\hline $101 \rightarrow 104$ & 0.10005 & & & \\
\hline $101 \rightarrow 105$ & 0.58730 & & & \\
\hline $103 \rightarrow 107$ & & & & \\
\hline $7(S)$ & 0.46263 & & & \\
\hline $102 \rightarrow 104$ & 0.42672 & & & \\
\hline $103 \rightarrow 105$ & -0.18292 & 3.4071 & 363.90 & 0.1405 \\
\hline $103 \rightarrow 106$ & -0.22746 & & & \\
\hline $103 \rightarrow 107$ & & & & \\
\hline $8(\mathrm{~T})$ & 0.38274 & & & \\
\hline $101 \rightarrow 104$ & -0.15712 & & & \\
\hline $101 \rightarrow 105$ & -0.28172 & & & \\
\hline $101 \rightarrow 106$ & -0.18264 & 3.4113 & 363.45 & 0.0000 \\
\hline $102 \rightarrow 106$ & 0.20011 & J.7111 & (3) & 0.0000 \\
\hline $103 \rightarrow 105$ & 0.29507 & & & \\
\hline $103 \rightarrow 106$ & -0.12290 & & & \\
\hline $103 \rightarrow 107$ & & & & \\
\hline
\end{tabular}


TABle 4: Continued.

\begin{tabular}{|c|c|c|c|c|}
\hline Excited state (triplet/singlet) & CI expansion coefficient & Energy $(\mathrm{eV})$ & Wavelength calc. (nm) & Oscillator Strength (f) \\
\hline $9(\mathrm{~T})$ & -0.31383 & \multirow{9}{*}{3.4452} & \multirow{9}{*}{359.88} & \multirow{8}{*}{0.0000} \\
\hline $99 \rightarrow 104$ & 0.12754 & & & \\
\hline $99 \rightarrow 105$ & -0.18356 & & & \\
\hline $100 \rightarrow 104$ & 0.15473 & & & \\
\hline $100 \rightarrow 105$ & -0.10501 & & & \\
\hline $100 \rightarrow 106$ & 0.10458 & & & \\
\hline $103 \rightarrow 105$ & 0.10831 & & & \\
\hline $103 \rightarrow 106$ & 0.48610 & & & \\
\hline \multicolumn{3}{|l|}{$103 \rightarrow 108$} & & \\
\hline $10(\mathrm{~T})$ & 0.26533 & \multirow{12}{*}{3.4968} & \multirow{12}{*}{354.56} & \multirow{12}{*}{0.0000} \\
\hline $98 \rightarrow 104$ & -0.17532 & & & \\
\hline $99 \rightarrow 104$ & 0.14537 & & & \\
\hline $99 \rightarrow 106$ & 0.25397 & & & \\
\hline $100 \rightarrow 104$ & 0.14670 & & & \\
\hline $101 \rightarrow 106$ & -0.13584 & & & \\
\hline $102 \rightarrow 104$ & 0.14197 & & & \\
\hline $102 \rightarrow 105$ & 0.10470 & & & \\
\hline $103 \rightarrow 104$ & 0.26216 & & & \\
\hline $103 \rightarrow 105$ & 0.28660 & & & \\
\hline $103 \rightarrow 106$ & 0.15214 & & & \\
\hline \multicolumn{2}{|l|}{$103 \rightarrow 107$} & & & \\
\hline $11(\mathrm{~S})$ & 0.28917 & & & \\
\hline $101 \rightarrow 104$ & -0.13634 & \multirow{5}{*}{3.5463} & \multirow{5}{*}{349.62} & \multirow{4}{*}{0.0491} \\
\hline $102 \rightarrow 104$ & 0.44769 & & & \\
\hline $103 \rightarrow 105$ & 0.37599 & & & \\
\hline $103 \rightarrow 106$ & 0.20752 & & & \\
\hline \multicolumn{3}{|l|}{$103 \rightarrow 107$} & & \\
\hline $12(\mathrm{~S})$ & 0.30776 & \multirow{6}{*}{3.6873} & \multirow{6}{*}{336.24} & \multirow{5}{*}{0.1203} \\
\hline $102 \rightarrow 104$ & 0.10328 & & & \\
\hline $102 \rightarrow 107$ & -0.23091 & & & \\
\hline $103 \rightarrow 105$ & 0.48945 & & & \\
\hline $103 \rightarrow 106$ & 0.24268 & & & \\
\hline \multicolumn{3}{|l|}{$103 \rightarrow 107$} & & \\
\hline $13(\mathrm{~T})$ & 0.13526 & \multirow{12}{*}{3.6887} & \multirow{12}{*}{336.12} & \multirow{11}{*}{0.0000} \\
\hline $99 \rightarrow 104$ & -0.17258 & & & \\
\hline $100 \rightarrow 104$ & 0.28909 & & & \\
\hline $101 \rightarrow 105$ & 0.14313 & & & \\
\hline $101 \rightarrow 106$ & -0.13298 & & & \\
\hline $101 \rightarrow 107$ & -0.14420 & & & \\
\hline $102 \rightarrow 105$ & 0.31031 & & & \\
\hline $102 \rightarrow 106$ & 0.21164 & & & \\
\hline $102 \rightarrow 107$ & 0.19945 & & & \\
\hline $103 \rightarrow 105$ & 0.22837 & & & \\
\hline $103 \rightarrow 106$ & -0.12402 & & & \\
\hline \multicolumn{3}{|l|}{$103 \rightarrow 107$} & & \\
\hline $14(\mathrm{~T})$ & 0.44193 & & & \\
\hline $98 \rightarrow 104$ & -0.13986 & & & \\
\hline $99 \rightarrow 105$ & -0.25100 & & & \\
\hline $101 \rightarrow 106$ & -0.21945 & 3.7249 & 332.85 & 0.0000 \\
\hline $102 \rightarrow 105$ & 0.22073 & & & \\
\hline $102 \rightarrow 107$ & -0.14380 & & & \\
\hline $103 \rightarrow 109$ & & & & \\
\hline
\end{tabular}


TABle 4: Continued.

\begin{tabular}{|c|c|c|c|c|}
\hline Excited state (triplet/singlet) & CI expansion coefficient & Energy $(\mathrm{eV})$ & Wavelength calc. (nm) & Oscillator Strength (f) \\
\hline $15(S)$ & 0.54944 & \multirow{6}{*}{3.7645} & \multirow{6}{*}{329.35} & \multirow{6}{*}{0.0736} \\
\hline $101 \rightarrow 104$ & 0.23402 & & & \\
\hline $102 \rightarrow 104$ & -0.19623 & & & \\
\hline $103 \rightarrow 105$ & -0.22900 & & & \\
\hline $103 \rightarrow 106$ & 0.18853 & & & \\
\hline $103 \rightarrow 107$ & & & & \\
\hline $16(S)$ & -0.28250 & \multirow{5}{*}{3.9579} & \multirow{5}{*}{313.25} & \multirow{5}{*}{0.1484} \\
\hline $101 \rightarrow 104$ & 0.39900 & & & \\
\hline $102 \rightarrow 104$ & 0.18195 & & & \\
\hline $102 \rightarrow 105$ & 0.46966 & & & \\
\hline $103 \rightarrow 107$ & & & & \\
\hline $17(S)$ & -0.11671 & \multirow{7}{*}{4.1055} & \multirow{7}{*}{301.99} & \multirow{7}{*}{0.0048} \\
\hline $96 \rightarrow 104$ & -0.24326 & & & \\
\hline $98 \rightarrow 104$ & 0.12165 & & & \\
\hline $99 \rightarrow 104$ & 0.57103 & & & \\
\hline $100 \rightarrow 104$ & -0.11945 & & & \\
\hline $103 \rightarrow 107$ & 0.22342 & & & \\
\hline $103 \rightarrow 108$ & & & & \\
\hline $18(\mathrm{~S})$ & 0.11882 & \multirow{4}{*}{4.1535} & \multirow{4}{*}{298.15} & \multirow{4}{*}{0.0127} \\
\hline $98 \rightarrow 104$ & -0.21315 & & & \\
\hline $100 \rightarrow 104$ & 0.64522 & & & \\
\hline $103 \rightarrow 108$ & & & & \\
\hline $19(S)$ & 0.15321 & \multirow{5}{*}{4.2776} & \multirow{4}{*}{289.84} & \multirow{4}{*}{0.0049} \\
\hline $96 \rightarrow 104$ & 0.45970 & & & \\
\hline $98 \rightarrow 104$ & 0.41273 & & & \\
\hline $99 \rightarrow 104$ & 0.19557 & & & \\
\hline $100 \rightarrow 104$ & & & & \\
\hline $20(S)$ & -0.30075 & \multirow{6}{*}{4.3829} & \multirow{6}{*}{$282.88(238)$} & \multirow{6}{*}{0.3427} \\
\hline $98 \rightarrow 104$ & 0.41155 & & & \\
\hline $99 \rightarrow 104$ & -0.21058 & & & \\
\hline $100 \rightarrow 104$ & 0.25420 & & & \\
\hline $102 \rightarrow 105$ & -0.28124 & & & \\
\hline $102 \rightarrow 106$ & & & & \\
\hline
\end{tabular}

investigated molecule has several sites for electrophilic as well as nucleophilic attacks as shown in MEP surface mapping.

4.5. UV-Vis Studies and Electronic Properties. To find the electronic absorption spectrum including singlet and triplet states of the title compound the calculations were performed on fully optimized ground state geometry using DFT/B3LYP/6-31++G(2d, 2p) level of theory. THF is used as a solvent to simulate the electronic absorption. Figure 6 represents the computed electronic spectra of the title compound. The electronic spectra are recorded within a range of $200 \mathrm{~nm}-800 \mathrm{~nm}$. Using TDDFT theory the oscillator strength along with excitation energy for the triplet and the singlet states has also been calculated. The different values for excitation energy along with oscillator strength as well as CI expansion coefficients are listed in Table 4. For the title compound the maximum absorption value obtained using TDDFT/B3LYP/6-311++G(2d, 2p) basis set are $485 \mathrm{~nm}, 332 \mathrm{~nm}$, and $285 \mathrm{~nm}$, respectively, with THF as solvent in CPCM model. Corresponding experimental values as reported are $383 \mathrm{~nm}$ and $258 \mathrm{~nm}$, respectively. The calculated band at $485 \mathrm{~nm}$ is intense and accounts for a $\pi \rightarrow \pi^{*}$ type of transition. $\lambda_{\max }$ absorption band in the calculated spectrum indicates a HOMO (103) $\rightarrow$ LUMO (104) transition and is close to experimentally calculated values.

4.6. Vibrational Spectra. In the present study we have reported the molecular vibrations of the title compound by means of FTIR spectroscopy. Our title compound is asymmetric top with C1-symmetry and is characterized by 141 normal modes of vibration. We have used DFT/B3LYP/6$311++G(2 d, 2 p)$ [23] method to investigate the normal modes of vibration of our title compound. The main reason for selecting this computational scheme is that it reproduces experimental frequencies with high accuracy and the same can be predicted from the comparison of the calculated values with the experimental ones. The calculated and experimental FTIR spectra of the title compound are shown in Figure 6. 


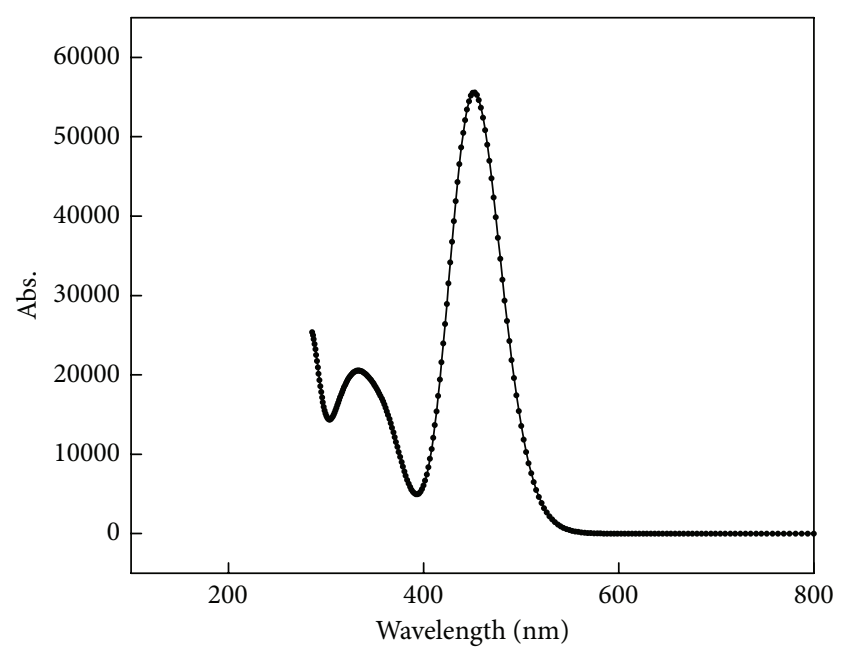

Figure 6: UV-Vis spectrum of (ethyl 4 hydroxy-3-((E)-(pyren-1ylimino)methyl)benzoate).

On comparison we found that the calculated values using the above method are found to be in close agreement with the experimental values. Calculated $\mathrm{C}-\mathrm{H}$ stretching vibrations of aromatic rings appeared in the wavenumber range 2800$3200 \mathrm{~cm}^{-1}$. The same has been confirmed with the experimental IR where the wavenumber range for aromatic rings ranges from 3000 to $3200 \mathrm{~cm}^{-1}$. The bands observed in the wavenumber range from 3250 to $2850 \mathrm{~cm}^{-1}$ in the calculated IR spectra of the title compound are assigned to the alkyl $\mathrm{C}-\mathrm{H}$ stretching vibrations and the same is confirmed with the experimental values. $\mathrm{C}=\mathrm{O}$ (ester) stretching vibrations are predicted at $1649 \mathrm{~cm}^{-1}$ while for the same functional group experimental values are at $1711 \mathrm{~cm}^{-1} . \mathrm{C}=\mathrm{N}$ (Schiff base) stretching vibrations are predicted at $1611 \mathrm{~cm}^{-1}$, while experimental values are at $1610 \mathrm{~cm}^{-1}$. We have also analyzed and reported our modes of vibrations in terms of PED. PED analysis is done by using VEDA 4 program [24]. This program generally uses the Gaussian output file in formatted checkpoint form as its input files for PED analysis. These input files contain information about orientation of coordinates, force constants (F-matrix), and frequencies with atom displacement matrix. The information on F-matrix must start form the line "Force Constants in Cartesian coordinates" (Figure 7).

We have repeated our PED analysis few hundred times to achieve maximum value of PED contributions. In PED interpretation each fundamental normal mode coordinate is expressed in terms of internal mode coordinates which is a combination of stretchings, bendings, or torsions. This transformation basically results in the nondiagonality of the force constant matrix, which means that PED contributions of different modes are mutually related to each other by nondiagonal terms. Further we explain how this procedure works as a normal mode coordinate is replaced by an internal set of coordinates and PEDs are calculated. A parameter EPm is used to express the maximum PEDs and is basically considered as optimization of the PED analysis. If our title compound consists of a large number of modes, then it will result in an increase of optimization time. Theoretically calculated and experimental wavenumbers (available) are summarized in Table 5. Detailed vibrational assignments, IR intensities, and computed wavenumbers along with the percentage of PED are given in Table 5. The spectra were analyzed in terms of the PED contributions by using the VEDA program.

4.6.1. Ring, $C=O$ and $C=N$ Vibrations. The $\mathrm{C}-\mathrm{H}$ stretching vibrations in the range $2800-3200 \mathrm{~cm}^{-1}$ are for aromatic compounds. From the PED analysis we found that $\mathrm{C}-\mathrm{H}$ stretching vibrations for ring 1 are assigned at $3183 \mathrm{~cm}^{-1}$. This mode is very pure mode as its PED analysis is about $99 \%$. The values observed in the range $(3158-3224) \mathrm{cm}^{-1}$ are assigned to the stretching vibrations of methyl hydrogen's while their experimentally obtained counterparts are at $3200 \mathrm{~cm}^{-1}$ and $3118 \mathrm{~cm}^{-1}$, respectively. The percentage of PED calculated for these modes by VEDA 4 program varies from 92 to $99 \%$ indicating that they are pure modes. $\mathrm{C}-\mathrm{N}$ modes of vibrations are assigned on the basis of PED calculations. In the PED analysis we found that $\mathrm{C}-\mathrm{N}$ modes of vibrations are at 1407 and $1387 \mathrm{~cm}^{-1}$ respectively, however these modes are not pure modes and are mixed with $\mathrm{C}-\mathrm{C}$ stretching modes, while experimentally observed value is at $1611 \mathrm{~cm}^{-1}$. On the basis of PED analysis the wavenumbers at $1648,1643,1675,1554$, and $1526 \mathrm{~cm}^{-1}$ are assigned to $\mathrm{C}=\mathrm{O}$ stretching modes, however again these modes are not pure modes and are mixed with other modes of vibrations. Experimentally obtained values for $\mathrm{C}=\mathrm{O}$ stretching modes is at $1649 \mathrm{~cm}^{-1}$. The PED analysis for various modes of the title compound along with their percentage values are summarized in Table 5.

4.7. NBO Analysis. In order to understand the hyper conjugation as well as delocalization of the title compound we have investigated the natural bond orbital analysis of the title compound using NBO 3.1 program implemented in Gaussian 09 package [25]. We have used DFT/B3LYP/6-311++G(2d, $2 \mathrm{p})$ level of theory in order to understand different kind of interactions between the filled and the vacant orbitals. We can investigate both intra- and intermolecular interactions using $\mathrm{NBO}$ analysis. In addition to this $\mathrm{NBO}$ analysis is also useful for understanding charge transfer conjugative interactions in different compounds. Using DFT/B3LYP/6-311++G(2d, 2p) level of theory the second-order perturbation theory analysis of Fock matrix in NBO basis [26] for title compound is listed in Table 6. For each donor $(i)$ and acceptor $(j)$ the stabilization energy $E(2)$ associated with the delocalization $i \rightarrow j$ is determined as

$$
E(2)=\Delta E_{i j} q_{i} \frac{\left(F_{i j}\right)^{2}}{\left(E_{j}-E_{i}\right)} .
$$

Large $E(2)$ value shows the intensive interaction between electron-donors and electron-acceptors groups and greater extent of conjugation of the whole system. The possible intensive interactions are also listed in Table 6. The secondorder perturbation theory analysis of Fock matrix in NBO 
TABLE 5: Vibrational wavenumbers obtained for the title compound at B3LYP/6-311++G $(2 \mathrm{~d}, 2 \mathrm{p})\left(\right.$ Harmonic frequency $\left.\left(\mathrm{cm}^{-1}\right), \mathrm{IR}_{\text {int }}\left(\mathrm{cm}^{-1}\right)\right)$.

\begin{tabular}{|c|c|c|c|c|c|}
\hline $\begin{array}{l}\text { Experimental } \\
\text { wavenumbers } \\
\left(\mathrm{cm}^{-1}\right)\end{array}$ & $\begin{array}{c}\text { Calculated } \\
\text { wavenumbers } \\
\left(\mathrm{cm}^{-1}\right)\end{array}$ & $\mathrm{IR}_{\text {int }}\left(\mathrm{cm}^{-1}\right)$ & $\operatorname{Raman}\left(\mathrm{cm}^{-1}\right)$ & PED & Interpretation \\
\hline & 3224.31 & 4.48 & 183.79 & s11 93 & $v_{s}\left(\mathrm{CH}_{2}\right)$, ring 1 \\
\hline & 3212.1 & 9.19 & 87.51 & s13 94 & $v_{s}\left(\mathrm{CH}_{2}\right)$, ring 4 \\
\hline \multirow[t]{4}{*}{3200} & 3205.53 & 2.7 & 72.41 & s3 94 & $v_{\text {as }}\left(\mathrm{CH}_{2}\right)$, ring 1 \\
\hline & 3191.45 & 60.42 & 530.75 & s19 97 & $v_{s}\left(\mathrm{CH}_{3}\right)$, ring 5 \\
\hline & 3189.28 & 27.8 & 114.52 & s14 92 & $v_{s}\left(\mathrm{CH}_{2}\right)$, ring 4 \\
\hline & 3183.94 & 1.57 & 36.38 & s4 99 & $v_{s}(\mathrm{CH})$, ring 1 \\
\hline \multirow[t]{8}{*}{3181} & 3181.15 & 51.58 & 278.89 & s18 96 & $v_{s}\left(\mathrm{CH}_{2}\right)$, ring 3 \\
\hline & 3171.65 & 24.78 & 229.97 & s12-13 s15-83 & $v_{\text {as }}\left(\mathrm{CH}_{2}\right)$, ring $5+v_{s}(\mathrm{CH})$, ring 4 \\
\hline & 3167.97 & 2.75 & 45.05 & s12 78 s15 -15 & $v_{\mathrm{as}}\left(\mathrm{CH}_{2}\right)$, ring $4+v_{s}\left(\mathrm{CH}_{2}\right)$, ring 5 \\
\hline & 3167.24 & 11.88 & 60.89 & s7 92 & $v_{\text {as }}\left(\mathrm{CH}_{2}\right)$, ring 2 \\
\hline & 3161.69 & 0.24 & 47.53 & s1793 & $v_{\text {as }}\left(\mathrm{CH}_{3}\right)$, ring 5 \\
\hline & 3158.71 & 1.74 & 40.37 & s16 93 & $v_{\mathrm{as}}\left(\mathrm{CH}_{2}\right), \operatorname{ring} 3$ \\
\hline & 3119.2 & 48.59 & 16.84 & $\begin{array}{l}\text { s5 }-13 \text { s6 }-10 \text { s } 8-17 \\
\text { s10 } 60\end{array}$ & Not defined \\
\hline & 3099.91 & 38.21 & 156.66 & s6 -81 & $v_{\mathrm{as}}\left(\mathrm{C}^{\mathrm{A}} \mathrm{H}_{2}\right)$ \\
\hline \multirow[t]{6}{*}{3090} & 3090.57 & 0.93 & 95.26 & S8 78 s10 -12 & $v_{\mathrm{as}}\left(\mathrm{C}^{\mathrm{A}} \mathrm{H}_{2}\right)+v_{s}\left(\mathrm{CH}_{2}\right)$ \\
\hline & 3059.21 & 20.49 & 88.61 & s2 99 & $v_{s}\left(\mathrm{C}^{\mathrm{A}} \mathrm{H}\right)$ \\
\hline & 3052.38 & 15.95 & 154.12 & s9 96 & $v_{s}\left(\mathrm{C}^{\mathrm{A}} \mathrm{H}_{2}\right)$ \\
\hline & 3029.99 & 26.36 & 191.4 & s5 76 s10 21 & $v_{s}\left(\mathrm{C}^{\mathrm{A}} \mathrm{H}_{3}\right)$ \\
\hline & 2894.86 & 785.16 & 225.28 & s1 96 & $v_{s}\left(\mathrm{C}^{\mathrm{A}} \mathrm{O}\right)$ \\
\hline & 1675.14 & 219.1 & 561.69 & s26-60 & $v_{s}\left(\mathrm{C}^{\mathrm{A}} \mathrm{O}\right)$ \\
\hline \multirow[t]{6}{*}{1711} & 1667.79 & 12.27 & 1522.05 & s39 42 & $v_{s}(\mathrm{C}-\mathrm{C}), \operatorname{ring} 3,4,5$ \\
\hline & 1648.5 & 371.86 & 211.55 & s20 32 s $23-10$ & $v_{s}\left(\mathrm{C}^{\mathrm{A}} \mathrm{O}\right)+v_{s}(\mathrm{C}-\mathrm{C}), \operatorname{ring} 1,4$ \\
\hline & 1643.33 & 51.26 & 229.63 & s20 -16 s $23-28$ & $v_{s}\left(\mathrm{C}^{\mathrm{A}} \mathrm{O}\right)+v_{s}(\mathrm{C}-\mathrm{C}), \operatorname{ring} 1,4$ \\
\hline & 1638.23 & 39.05 & 1129.96 & $s 23-16$ s $28-22$ & $v_{\text {as }}(\mathrm{C}-\mathrm{C}), \operatorname{ring} 3+v_{\text {as }}(\mathrm{C}-\mathrm{C}), \operatorname{ring} 4$ \\
\hline & 1629.61 & 22.25 & 3026.04 & s21 11 s $28-23$ & $v_{s}(\mathrm{C}-\mathrm{C}), \operatorname{ring} 1+v_{\mathrm{as}}(\mathrm{C}-\mathrm{C})$, ring 5 \\
\hline & 1622.07 & 16.12 & 824.95 & s27 13 s81 11 & $v_{s}(\mathrm{C}-\mathrm{C})$, ring $4+\beta \mathrm{CCC}$, ring 5 \\
\hline \multirow[t]{16}{*}{1610} & 1610.7 & 78.32 & 8784.86 & s35 27 & $v_{s}\left(\mathrm{C}^{\mathrm{A}} \mathrm{N}\right)$ \\
\hline & 1583.63 & 8.54 & 225.08 & s36 $21 \mathrm{~s} 39-10 \mathrm{~s} 6011$ & $\begin{array}{c}v_{s}(\mathrm{C}-\mathrm{C}), \operatorname{ring} 2+v_{\mathrm{as}}(\mathrm{C}-\mathrm{C}), \operatorname{ring} 3+ \\
\beta \mathrm{HCC}, \text { ring } 3\end{array}$ \\
\hline & 1554.36 & 6.42 & 3.52 & s62 70 s101 15 & $\beta \mathrm{HCC}+\tau \mathrm{HCOC},\left(\mathrm{OC}^{\mathrm{A}}\right)$ \\
\hline & 1546.99 & 13.7 & 1548.31 & s33 16 s68-24 & $v_{s}(\mathrm{C}-\mathrm{C})$, ring $3+\beta \mathrm{HCC}$, ring 2 \\
\hline & 1539.54 & 8.07 & 29.88 & s61 70 s62 -10 s103 10 & $\begin{array}{c}\beta \mathrm{HCH}, 0020\left(\mathrm{HC}^{\mathrm{A}}\right)+\beta \mathrm{HCH},\left(\mathrm{HC}^{\mathrm{A}}\right)+ \\
\tau \mathrm{HCOC},\left(\mathrm{OC}^{\mathrm{A}}\right)\end{array}$ \\
\hline & 1526.21 & 9.1 & 23.7 & s59 73 s100 -12 & $\beta \mathrm{HCH},\left(\mathrm{HC}^{\mathrm{A}}\right)+\tau \mathrm{HCOC},\left(\mathrm{OC}^{\mathrm{A}}\right)$ \\
\hline & 1524.23 & 37.79 & 260.32 & s25 12 s72-10 & $v_{s}(\mathrm{C}=\mathrm{C})$, ring $5+\beta \mathrm{HCH}$, ring 1 \\
\hline & 1518.08 & 71.68 & 2628.38 & s25 11 s $55-14$ s $56-10$ & $v_{s}(\mathrm{C}=\mathrm{C})$, ring $2+\beta \mathrm{HCC}$, ring 1 \\
\hline & 1495.75 & 21.77 & 369.81 & s67 -25 & $\beta \mathrm{HCC}$, ring 3 \\
\hline & 1493.07 & 89.53 & 2975.2 & s35 -13 s54 17 & $v_{s}\left(\mathrm{C}^{\mathrm{A}} \mathrm{N}\right)+\beta \mathrm{HOC}$ \\
\hline & 1476.41 & 4.86 & 4.47 & s60 22 & $\beta \mathrm{HOC}$ \\
\hline & 1465.71 & 3.62 & 246.14 & s71-65 & $\beta \mathrm{HCC}$, ring 5 \\
\hline & 1457.66 & 12.6 & 15.74 & s63 84 & $\beta \mathrm{HCC},\left(\mathrm{HC}^{\mathrm{A}}\right)$ \\
\hline & 1451.13 & 6.85 & 16.4 & s54-11 & $\beta \mathrm{HOC},\left(\mathrm{OC}^{\mathrm{A}}\right)$ \\
\hline & 1444.01 & 6.01 & 106.44 & $s 29-15 s 6910$ & $v_{s}(\mathrm{C}-\mathrm{C})$, ring $5+\beta \mathrm{HCC}$, ring 3 \\
\hline & 1422.52 & 3.56 & 1171.11 & s22 34 & $v_{s}(\mathrm{C}=\mathrm{C}), \operatorname{ring} 2$ \\
\hline
\end{tabular}


TABle 5: Continued.

\begin{tabular}{|c|c|c|c|c|c|}
\hline $\begin{array}{l}\text { Experimental } \\
\text { wavenumbers } \\
\left(\mathrm{cm}^{-1}\right)\end{array}$ & $\begin{array}{c}\text { Calculated } \\
\text { wavenumbers } \\
\left(\mathrm{cm}^{-1}\right)\end{array}$ & $\operatorname{IR}_{\text {int }}\left(\mathrm{cm}^{-1}\right)$ & $\operatorname{Raman}\left(\mathrm{cm}^{-1}\right)$ & PED & Interpretation \\
\hline & 1418.96 & 8.01 & 160.33 & s62 $11 s 10167$ & $\beta \mathrm{HCH},\left(\mathrm{HC}^{\mathrm{A}}\right)+\tau \mathrm{HCOC},\left(\mathrm{OC}^{\mathrm{A}}\right)$ \\
\hline & 1407.13 & 11.57 & 189.62 & s31-23 s64 -17 & $v_{\text {as }}(\mathrm{C}-\mathrm{C}), \operatorname{ring} 5+\beta \mathrm{HCN},\left(\mathrm{NC}^{\mathrm{A}}\right)$ \\
\hline & 1387.02 & 4.94 & 692.54 & s31-11 s64 31 & $v_{\mathrm{as}}(\mathrm{C}-\mathrm{C}), \operatorname{ring} 5+\beta \mathrm{HCN},\left(\mathrm{NC}^{\mathrm{A}}\right)$ \\
\hline & 1371.3 & 53.01 & 744.64 & s24-51s42 13 & $v_{\text {as }}(\mathrm{C}-\mathrm{C}), \operatorname{ring} 1+v_{s}(\mathrm{C}-\mathrm{C}), \operatorname{ring} 5$ \\
\hline & 1365.37 & 3.17 & 20.73 & s85 10 & $\beta \mathrm{CCC}$, ring 4 \\
\hline & 1347.53 & 8.32 & 30.53 & s37 $-41 \mathrm{~s} 66-10$ & $v_{\text {as }}(\mathrm{C}=\mathrm{C}), \operatorname{ring} 2+\beta \mathrm{HCC}, \operatorname{ring} 4$ \\
\hline & 1322.41 & 32.6 & 186.95 & s56-45 & $\beta \mathrm{HCC}$, ring 1 \\
\hline & 1301.85 & 0.32 & 18.48 & s58 76 & $\beta \mathrm{HCC},\left(\mathrm{C}^{\mathrm{A}} \mathrm{H}\right)$ \\
\hline & 1293.46 & 1.16 & 19.8 & s33 12 s60 10 s68 21 & $\begin{array}{c}v_{\text {as }}(\mathrm{C}-\mathrm{C}), \operatorname{ring} 3+\beta \mathrm{HCC}, \operatorname{ring} 4+ \\
\beta \mathrm{HCC}, \text { ring } 5\end{array}$ \\
\hline & 1290.84 & 115.58 & 764.31 & s30 58 & $v_{s}(\mathrm{CO}),\left(\mathrm{C}^{\mathrm{A}} \mathrm{O}\right)$ \\
\hline & 1284.22 & 2.96 & 455.48 & s41 20 s69-17 & $v_{s}(\mathrm{C}-\mathrm{C})$, ring $5+\beta \mathrm{HCC}$, ring 5 \\
\hline & 1264.63 & 151.27 & 24.03 & s26 -16 s57 -14 & $v_{\mathrm{as}}(\mathrm{C}-\mathrm{C}), \operatorname{ring} 5+\beta \mathrm{HCC}, \operatorname{ring} 1$ \\
\hline & 1263.15 & 62.22 & 3895.41 & $\mathrm{~s} 41-11 \mathrm{~s} 44-11$ & $+v_{\mathrm{as}}(\mathrm{C}-\mathrm{C}), \operatorname{ring} 1+v_{\mathrm{as}}(\mathrm{C}-\mathrm{C}), \operatorname{ring} 5$ \\
\hline & 1252.17 & 107.36 & 376.98 & & Not defined \\
\hline & 1231.74 & 194.37 & 485.07 & s32-10 s72 21 & $v_{\mathrm{as}}(\mathrm{C}-\mathrm{C})$, ring $2+\beta \mathrm{HCC}$, ring 5 \\
\hline & 1223.49 & 154.6 & 440.05 & s70 -52 & $\beta \mathrm{HCC}$, ring 2 \\
\hline & 1211.31 & 266.52 & 575.9 & s70 -13 & $\beta \mathrm{HCC}$, ring 2 \\
\hline & 1196.58 & 52.39 & 47.76 & s25 17 s66 40 & $v_{s}(\mathrm{C}=\mathrm{C})$, ring $4+\beta \mathrm{HCC}$, ring 5 \\
\hline & 1190.05 & 0.98 & 29.65 & s39 14s65 49 & $v_{s}(\mathrm{C}=\mathrm{C})$, ring $3+\beta \mathrm{HCC}$, ring 3 \\
\hline & 1188.46 & 5.77 & 4.66 & s58 -14 s100 54 & $\beta \mathrm{HCC}\left(\mathrm{C}^{\mathrm{A}} \mathrm{H}\right)+\tau \mathrm{HCOC},\left(\mathrm{OC}^{\mathrm{A}}\right)$ \\
\hline & 1163.11 & 62.3 & 4.06 & s29 $25 s 5755$ & $v_{s}(\mathrm{C}=\mathrm{C})$, ring $1+\beta \mathrm{HCC}$, ring 1 \\
\hline & 1147.16 & 3.05 & 19.94 & $\begin{array}{c}\text { s } 4822 \mathrm{~s} 61-18 \mathrm{~s} 94-12 \\
\mathrm{~s} 103-32\end{array}$ & $\beta \mathrm{HCH}\left(\mathrm{C}^{\mathrm{A}} \mathrm{H}\right)+\underset{\left(\mathrm{OC}^{\mathrm{A}}\right)}{\beta \mathrm{CCO}\left(\mathrm{C}^{\mathrm{A}} \mathrm{O}\right)+\tau \mathrm{HCCO}}$ \\
\hline & 1143.32 & 0.51 & 14.59 & s77 32 & $\beta$ CCC, ring 4 \\
\hline & 1132.55 & 18.83 & 225.65 & s69 11 & $\beta \mathrm{HCC}$, ring 5 \\
\hline & 1118.58 & 268.59 & 4.61 & s46-31 s55 15 & $v_{\mathrm{as}}(\mathrm{C}=\mathrm{C}), \operatorname{ring} 1+\beta \mathrm{HCC}$, ring 1 \\
\hline & 1085.93 & 16.59 & 30.98 & s27 14 s34 22 & $v_{s}(\mathrm{C}=\mathrm{C})$, ring $3+v_{s}(\mathrm{C}=\mathrm{C})$, ring 5 \\
\hline & 1039.71 & 88.12 & 4.02 & s47 72 & $v_{\mathrm{as}}(\mathrm{C}=\mathrm{C}),\left(\mathrm{C}^{\mathrm{A}} \mathrm{H}\right)$ \\
\hline & 1037.69 & 2.7 & 6.89 & s102-80 & $\tau$ HCCC, ring 4 \\
\hline & 1015.71 & 1 & 19.59 & s112-52 & $\tau \mathrm{HCCC}$, ring 5 \\
\hline & 1014.43 & 16.39 & 160.22 & s99-66 & $\tau \mathrm{HCNC},\left(\mathrm{C}^{\mathrm{A}} \mathrm{N}\right)$ \\
\hline & 1005.48 & 0.18 & 0.64 & s113 61 & $\tau \mathrm{HCCC}$, ring 3 \\
\hline & 1004.51 & 5.05 & 79.88 & s106 74 & $\tau$ HCCC, ring 1 \\
\hline & 995.67 & 6.4 & 4.17 & s32 $10 \mathrm{~s} 40-12$ & $v_{s}(\mathrm{C}-\mathrm{C}), \operatorname{ring} 2+v_{\mathrm{as}}(\mathrm{C}=\mathrm{C}), \operatorname{ring} 3$ \\
\hline & 982.59 & 1.21 & 30.45 & s109 66 & $\tau \mathrm{HCCC}$, ring 2 \\
\hline & 966.87 & 5.99 & 189.31 & s97 38 & $\tau \mathrm{HCCC}$, ring 1 \\
\hline & 964.36 & 22.39 & 3.01 & s97 44 & $\tau$ HCCC, ring 1 \\
\hline & 957.27 & 80.57 & 1.93 & s96 75 & $\tau \mathrm{HOCC}\left(\mathrm{C}^{\mathrm{A}} \mathrm{O}\right)$ \\
\hline & 938.59 & 1.65 & 4.09 & s110 72 & $\tau \mathrm{HCCC}$, ring 5 \\
\hline & 925.25 & 33.74 & 166.09 & s44-11 s79-27 & $v_{\mathrm{as}}\left(\mathrm{C}^{\mathrm{A}} \mathrm{N}\right)+\beta \mathrm{CCC}, \operatorname{ring} 4$ \\
\hline & 881.43 & 111.2 & 18.99 & s108 -60 & $\tau \mathrm{HCCC}$, ring 2 \\
\hline & 876.59 & 42.03 & 10.19 & s48-12 s107 25 & $v_{\mathrm{as}}(\mathrm{C}-\mathrm{C})$, ring $1+\tau \mathrm{HCCC}$, ring 4 \\
\hline & 867.61 & 38.53 & 2.37 & s98 60 & $\tau$ HCCC, ring 1 \\
\hline & 866.7 & 25.46 & 2.94 & $\begin{array}{l}\text { s } 48-16 \text { s } 98-21 \text { s } 107 \\
-12 \text { s108 }-14\end{array}$ & Not defined \\
\hline
\end{tabular}


TABle 5: Continued.

\begin{tabular}{|c|c|c|c|c|c|}
\hline $\begin{array}{l}\text { Experimental } \\
\text { wavenumbers } \\
\left(\mathrm{cm}^{-1}\right)\end{array}$ & $\begin{array}{c}\text { Calculated } \\
\text { wavenumbers } \\
\left(\mathrm{cm}^{-1}\right)\end{array}$ & $\mathrm{IR}_{\text {int }}\left(\mathrm{cm}^{-1}\right)$ & $\operatorname{Raman}\left(\mathrm{cm}^{-1}\right)$ & PED & Interpretation \\
\hline & 846.41 & 10.78 & 2.34 & s50 -54 & $\beta \mathrm{CCC}$, ring 4 \\
\hline & 833.53 & 3.4 & 6.97 & s107 14 s111 31 & $\tau \mathrm{HCCC}$, ring $1+\tau \mathrm{HCCC}$, ring 3 \\
\hline & 830.77 & 0.38 & 2.5 & s104 70 & $\tau \mathrm{HCCO},\left(\mathrm{C}^{\mathrm{A}} \mathrm{O}\right)$ \\
\hline & 828.69 & 9.21 & 66.05 & s111 21 & $\tau \mathrm{HCCC}$, ring 2 \\
\hline & 815.14 & 3.69 & 7.4 & s128 -18 & $\tau \mathrm{CCCC}$, ring 5 \\
\hline & 804.43 & 1.77 & 4.67 & s73-27 & $\beta \mathrm{OCO},\left(\mathrm{C}^{\mathrm{A}} \mathrm{O}\right)$ \\
\hline & 793.29 & 1.08 & 59.46 & s4320s82 18 & $v_{s}(\mathrm{C}-\mathrm{C})$, ring $1+\beta \mathrm{CCC}$, ring 4 \\
\hline & 778.97 & 8.82 & 4.11 & s114 67 & $\tau \mathrm{HCCC}$, ring 5 \\
\hline & 764.69 & 5.88 & 9.65 & s82 17 & $\beta C C C$, ring 1 \\
\hline & 760.34 & 19.23 & 0.69 & s136 -51 & $\phi \mathrm{CCCC}$, ring 1 \\
\hline & 741.78 & 17.23 & 0.25 & $\begin{array}{c}\mathrm{s} 107-12 \mathrm{~s} 11111 \mathrm{~s} 116 \\
-11\end{array}$ & $\begin{array}{c}\tau \mathrm{HCCC}, \operatorname{ring} 1+\tau \mathrm{HCCC}, \operatorname{ring} 4+ \\
\tau \mathrm{CCCC}, \text { ring } 5\end{array}$ \\
\hline & 724.92 & 6.87 & 6.4 & s141 55 & $\phi \mathrm{OCOC},\left(\mathrm{C}^{\mathrm{A}} \mathrm{O}\right)$ \\
\hline & 714.44 & 0.19 & 18.14 & s28 $-11 \mathrm{~s} 4916$ & $v_{s}(\mathrm{C}-\mathrm{C})$, ring $3+\beta \mathrm{CCC}$, ring 4 \\
\hline & 702.64 & 8.92 & 32.91 & $\begin{array}{c}\mathrm{s} 120-15 \mathrm{~s} 138-10 \mathrm{~s} 140 \\
-24\end{array}$ & $\begin{array}{c}\tau \mathrm{CCCC}, \text { ring } 1+\phi \mathrm{CCCC}, \text { ring } 2+ \\
\phi \mathrm{CCCC}, \operatorname{ring} 3\end{array}$ \\
\hline & 676.97 & 30.47 & 11.99 & s41 11 s93 14 & $v_{s}(\mathrm{C}-\mathrm{C})$, ring $1+\beta \mathrm{CCO},\left(\mathrm{C}^{\mathrm{A}} \mathrm{O}\right)$ \\
\hline & 651.45 & 14.72 & 11.48 & s51-35 & $\beta$ CCC, ring 1 \\
\hline & 640.97 & 13.61 & 40.41 & s126 12 s129 -11 & $\tau \mathrm{CCNC}$, ring $1+\tau \mathrm{CCCC}$, ring 1 \\
\hline & 622.1 & 2.3 & 28.46 & s38-13 s80 17 & $v_{s}(\mathrm{C}-\mathrm{C})$, ring $3+\beta \mathrm{CCN},\left(\mathrm{C}^{\mathrm{A}} \mathrm{N}\right)$ \\
\hline & 578.44 & 0.11 & 9.98 & s41 $10 \mathrm{~s} 4910$ & $v_{s}(\mathrm{C}-\mathrm{C})$, ring $3+\beta \mathrm{CCC}$, ring 5 \\
\hline & 568.57 & 2.75 & 12.66 & $\begin{array}{c}\text { s121 }-11 \text { s122 -12 s124 } \\
-11 \mathrm{~s} 13915\end{array}$ & Not defined \\
\hline & 559.84 & 0.71 & 13.11 & s122 23 s124 10 s134 19 & $\begin{array}{c}\tau \mathrm{CCCC}, \text { ring } 1+\tau \mathrm{CCCC}, \text { ring } 3+ \\
\phi \mathrm{CCCC}, \text { ring } 5\end{array}$ \\
\hline & 546.17 & 11.74 & 2.14 & & Not defined \\
\hline & 537.81 & 3.67 & 6.23 & s52 24 & $\beta \mathrm{CCO},\left(\mathrm{C}^{\mathrm{A}} \mathrm{O}\right)$ \\
\hline & 530.02 & 1.06 & 12.8 & s117 24 s139 13 & $\tau \mathrm{CCCN},\left(\mathrm{C}^{\mathrm{A}} \mathrm{N}\right)+\phi \mathrm{CCCC}$, ring 3 \\
\hline & 521.45 & 3.05 & 74.21 & s125 22 s127 14 & $\tau \mathrm{CCCC}$, ring $3+\tau \mathrm{CCNC},\left(\mathrm{C}^{\mathrm{A}} \mathrm{N}\right)$ \\
\hline & 512.46 & 0.83 & 1.44 & s88 23 & $\beta$ CCC, ring 3 \\
\hline & 497.39 & 3.19 & 11.62 & s76 -14 s83 11 s85-15 & 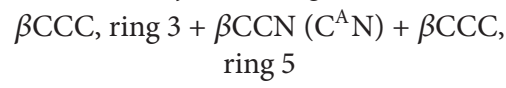 \\
\hline & 483.98 & 2.27 & 2.37 & s123 - 24 s135 24 & $\tau \mathrm{CCCC}$, ring $1+\phi \mathrm{CCCC}$, ring 2 \\
\hline & 460.5 & 1.9 & 6.03 & s87 20 & $\beta \mathrm{CCC}$, ring 4 \\
\hline & 444.53 & 1.19 & 3.6 & s124 10 & $\tau \mathrm{CCCC}$, ring 1 \\
\hline & 432.84 & 0.68 & 21.66 & s91 41 & $\beta \operatorname{CCO}\left(\mathrm{C}^{\mathrm{A}} \mathrm{O}\right)$ \\
\hline & 415.6 & 2.46 & 89.07 & s22-11 s90-14 & $v_{\mathrm{as}}(\mathrm{C}-\mathrm{C})$, ring $4+\beta \mathrm{CCC}$, ring 3 \\
\hline & 386.89 & 0.5 & 1.35 & s86-10 & $\beta \mathrm{CCC}$, ring 2 \\
\hline & 372.32 & 11.47 & 1.34 & s75-16s94 56 & $\beta \mathrm{COC},\left(\mathrm{C}^{\mathrm{A}} \mathrm{O}\right)+\beta \mathrm{CCO},\left(\mathrm{C}^{\mathrm{A}} \mathrm{O}\right)$ \\
\hline & 355.13 & 1.38 & 4.26 & s12319 s135 10 & $\tau \mathrm{CCCC}$, ring $3+\phi \mathrm{CCCC}$, ring 5 \\
\hline & 346.91 & 3.4 & 73.7 & s115-11 & $\tau \mathrm{NCCC},\left(\mathrm{C}^{\mathrm{A}} \mathrm{N}\right)$ \\
\hline & 311.17 & 4.64 & 20.43 & s45-15 s95 31 & $v_{\text {as }}(\mathrm{C}-\mathrm{C})$, ring $4+\beta \mathrm{COC},\left(\mathrm{C}^{\mathrm{A}} \mathrm{O}\right)$ \\
\hline & 289.37 & 5.1 & 68.61 & s115 24 & $\tau \mathrm{NCCC},\left(\mathrm{C}^{\mathrm{A}} \mathrm{N}\right)$ \\
\hline & 273 & 0.46 & 2.42 & s105-10 s121 17 s139 15 & $\begin{array}{c}\tau \mathrm{CCCO},\left(\mathrm{C}^{\mathrm{A}} \mathrm{O}\right)+\tau \mathrm{CCCC}, \text { ring } 3+ \\
\phi \mathrm{CCC}, \text { ring } 5\end{array}$ \\
\hline & 267.89 & 0.58 & 7.14 & s75 13 & $\beta \mathrm{COC},\left(\mathrm{C}^{\mathrm{A}} \mathrm{O}\right)$ \\
\hline & 252.25 & 1.23 & 10.57 & s103 12s105 55 & $\tau \mathrm{CCCO},\left(\mathrm{C}^{\mathrm{A}} \mathrm{O}\right)$ \\
\hline
\end{tabular}


TABLE 5: Continued.

\begin{tabular}{|c|c|c|c|c|c|}
\hline $\begin{array}{l}\text { Experimental } \\
\text { wavenumbers } \\
\left(\mathrm{cm}^{-1}\right)\end{array}$ & $\begin{array}{c}\text { Calculated } \\
\text { wavenumbers } \\
\left(\mathrm{cm}^{-1}\right)\end{array}$ & $\mathrm{IR}_{\text {int }}\left(\mathrm{cm}^{-1}\right)$ & $\operatorname{Raman}\left(\mathrm{cm}^{-1}\right)$ & PED & Interpretation \\
\hline & 241.04 & 2.81 & 9.87 & s75 12 & $\beta \mathrm{COC},\left(\mathrm{C}^{\mathrm{A}} \mathrm{O}\right)$ \\
\hline & 223.33 & 8.26 & 10.27 & s138-43 & $\phi \mathrm{CCCC}$, ring 4 \\
\hline & 186.81 & 5.98 & 7.28 & s89 12s116 - 17 & $\beta \operatorname{CCC},\left(\mathrm{C}^{\mathrm{A}}\right)+\tau \mathrm{CCCN},\left(\mathrm{C}^{\mathrm{A}} \mathrm{N}\right)$ \\
\hline & 171.6 & 0.34 & 10.17 & & Not defined \\
\hline & 152.06 & 7.4 & 9.77 & s118 24 s133 37 & $\tau \mathrm{CCCC}, \operatorname{ring} 1+\phi \mathrm{COCC},\left(\mathrm{C}^{\mathrm{A}} \mathrm{O}\right)$ \\
\hline & 134.24 & 3.04 & 26.07 & s75 -10 & $\beta \operatorname{COC}\left(\mathrm{C}^{\mathrm{A}} \mathrm{O}\right)$ \\
\hline & 122.64 & 0.08 & 11.46 & s119 15 s129 -11 & $\tau \mathrm{CCCN},\left(\mathrm{C}^{\mathrm{A}} \mathrm{N}\right)+\tau \mathrm{CCNC},\left(\mathrm{C}^{\mathrm{A}} \mathrm{N}\right)$ \\
\hline & 100.65 & 1.28 & 6.44 & s119 10 s127 14 & $\tau \mathrm{CCCN},\left(\mathrm{C}^{\mathrm{A}} \mathrm{N}\right)+\tau \mathrm{CCNC},\left(\mathrm{C}^{\mathrm{A}} \mathrm{N}\right)$ \\
\hline & 92.61 & 0.67 & 7.41 & $\begin{array}{c}\text { s118 } 11 \mathrm{~s} 131-15 \mathrm{~s} 133 \\
-20 \mathrm{~s} 13413\end{array}$ & $\tau \mathrm{COCC},\left(\mathrm{C}^{\mathrm{A}} \mathrm{O}\right)$ \\
\hline & 79.9 & 0.64 & 3.96 & s92 23 s131 12 & $\beta \mathrm{CCC}$, ring $4+\tau \mathrm{COCC},\left(\mathrm{C}^{\mathrm{A}} \mathrm{O}\right)$ \\
\hline & 59.62 & 0.88 & 2.9 & s130 -16 s131-37 & $\tau \mathrm{COCC},\left(\mathrm{C}^{\mathrm{A}} \mathrm{O}\right)$ \\
\hline & 39.59 & 0.12 & 2.58 & s130 48 s131 13 s132 - 11 & $\tau \mathrm{COCC},\left(\mathrm{C}^{\mathrm{A}} \mathrm{O}\right)$ \\
\hline & 31.93 & 0.14 & 5.25 & $\mathrm{~s} 74-42$ & $\beta \mathrm{CNC}\left(\mathrm{C}^{\mathrm{A}} \mathrm{N}\right)$ \\
\hline & 21.6 & 0.27 & 6.59 & s126 12 s132 47 & $\tau \mathrm{CCNC},\left(\mathrm{C}^{\mathrm{A}} \mathrm{N}\right)+\tau \mathrm{COCC},\left(\mathrm{C}^{\mathrm{A}} \mathrm{O}\right)$ \\
\hline & 16.34 & 0.3 & 8.44 & $\begin{array}{c}\text { s126 } 18 \mathrm{~s} 132-22 \mathrm{~s} 135 \\
12\end{array}$ & $\begin{array}{c}\tau \mathrm{CCNC},\left(\mathrm{C}^{\mathrm{A}} \mathrm{N}\right)+\tau \mathrm{COCC},\left(\mathrm{C}^{\mathrm{A}} \mathrm{O}\right)+ \\
\phi \mathrm{CCCC}, \text { ring } 3\end{array}$ \\
\hline
\end{tabular}

$v, \beta, \tau$, and $\phi$ denote the stretching, bending, torsion, and out ( $\phi \mathrm{ABCD}$ means the angle between the $\mathrm{AD}$ vector and the $\mathrm{BCD}$ plane) modes. Indices notation: s: symmetric; as: asymmetric; A: aliphatic; ring 1: C1-C2-C3-C4-C5-C6; ring 2: C15-C16-C17-C18-C19-C20; ring 3: C21-C22-C23-C24-C16-C17; ring 4: C17-C18C24-C25-C26-C27; ring 5: C23-C24-C25-C28-C29-C30.

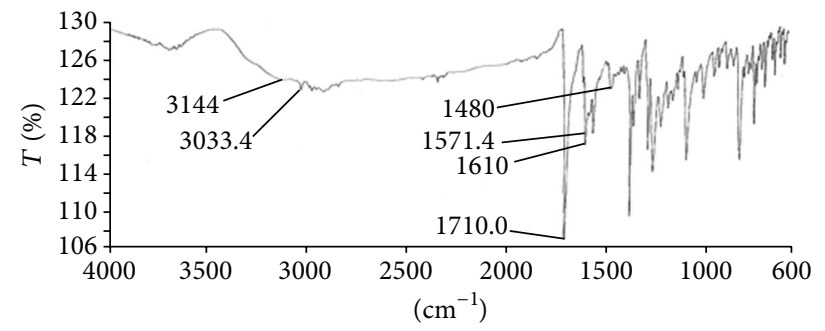

(a)

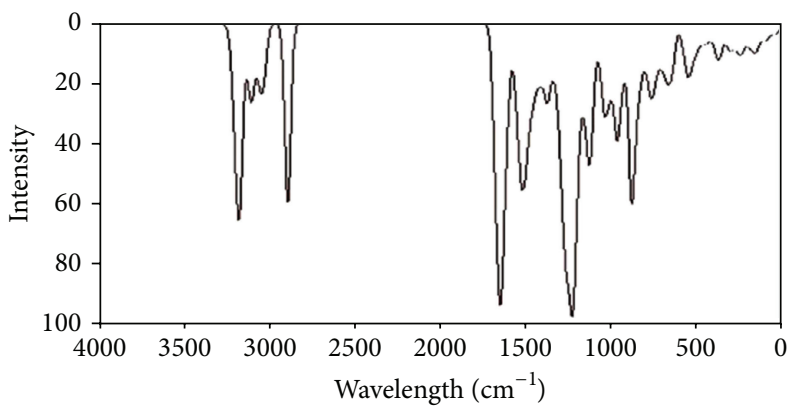

(b)

FIgURE 7: The experimental (a) [1] ${ }^{*}$ and calculated (b) IR of the title compound.

basis shows strong intramolecular hyper conjugative interactions of $\pi$ electrons. From Table 6 we can see that the intramolecular hyper conjugative interactions are formed by the orbital overlap between oxygen, nitrogen, and carboncarbon bond orbitals. This orbital overlapping is responsible for ICT causing stabilization of the system under study. From the analysis of Table 6 we found that the strong intramolecular hyper conjugative interaction is of C7-O9 from $\mathrm{n} 2(\mathrm{O} 8) \rightarrow \pi^{*}(\mathrm{C} 7-\mathrm{O} 9)$ which increases $\mathrm{ED}(0.10070 \mathrm{e})$ that weakens the respective bonds leading to stabilization of $32.78 \mathrm{kcal} \mathrm{mol}^{-1}$. Similarly another strong intramolecular hyper conjugative interaction of $\mathrm{C} 7-\mathrm{O} 8$ from $\mathrm{n} 2(\mathrm{O} 9) \rightarrow$ $\pi^{*}(\mathrm{C} 7-\mathrm{O} 8)$ increases ED $(0.28565 \mathrm{e})$ that weakens the respective bonds leading to stabilization of $46.67 \mathrm{kcal} \mathrm{mol}^{-1}$. We have also found another strong intramolecular hyper conjugative interaction of C21-C22 from $\mathrm{nl}(\mathrm{C} 23) \rightarrow \pi^{*}$ (C21$\mathrm{C} 22)$ which increases $\mathrm{ED}(0.18831 \mathrm{e})$ that also weakens the respective bonds leading to stabilization of $46.88 \mathrm{kcal} \mathrm{mol}^{-1}$. We predicted one more strong intramolecular hyper conjugative interaction of $\mathrm{C} 21-\mathrm{C} 22$ from $\mathrm{nl}(\mathrm{C} 23) \rightarrow \pi^{*}(\mathrm{C} 21-\mathrm{C} 22)$ which increases ED $(0.18831 \mathrm{e})$ that weakens the respective bonds leading to stabilization of $46.88 \mathrm{kcal} \mathrm{mol}^{-1}$, as well as strong intramolecular hyper conjugative interaction of $\mathrm{C} 24-\mathrm{C} 25$ from $\mathrm{nl}(\mathrm{C} 23) \rightarrow \pi^{*}(\mathrm{C} 24-\mathrm{C} 25)$ which increases $\mathrm{ED}(0.46625 \mathrm{e})$ that weakens the respective bonds leading to stabilization of $71.49 \mathrm{kcal} \mathrm{mol}^{-1}$. These interactions are observed as an increase in electron density (ED) in C-C antibonding orbitals that weakens the respective bonds. 
TABLE 6: Second-order perturbation theory analysis of Fock matrix in NBO basis.

\begin{tabular}{|c|c|c|c|c|c|c|c|c|}
\hline Donor $(i)$ & Type & $\mathrm{ED} / \mathrm{e}$ & Acceptor $(j)$ & Type & $\mathrm{ED} / \mathrm{e}$ & $E(2)^{\mathrm{a}}\left(\mathrm{kcalmol}^{-1}\right)$ & $E(j)-E(i)^{\mathrm{b}}(\mathrm{a} . \mathrm{u})$ & $F(i, j)^{\mathrm{c}}(\mathrm{a} . \mathrm{u})$ \\
\hline $\mathrm{C} 1-\mathrm{C} 2$ & $\pi$ & 1.68952 & $\mathrm{C} 3-\mathrm{C} 4$ & $\pi^{*}$ & 0.45595 & 25.08 & 0.26 & 0.075 \\
\hline $\mathrm{C} 1-\mathrm{C} 2$ & $\pi$ & 1.68952 & $\mathrm{C} 5-\mathrm{C} 6$ & $\pi^{*}$ & 0.35531 & 15.88 & 0.28 & 0.060 \\
\hline C1-C6 & $\sigma$ & 1.63511 & $\mathrm{C} 9-\mathrm{C} 10$ & $\sigma^{*}$ & 0.34194 & 4.65 & 1.25 & 0.068 \\
\hline $\mathrm{C} 3-\mathrm{C} 4$ & $\pi$ & 1.55498 & $\mathrm{C} 1-\mathrm{C} 2$ & $\pi^{*}$ & 0.27464 & 13.45 & 0.29 & 0.058 \\
\hline $\mathrm{C} 3-\mathrm{C} 4$ & $\pi$ & 1.55498 & $\mathrm{C} 5-\mathrm{C} 6$ & $\pi^{*}$ & 0.35531 & 25.35 & 0.28 & 0.077 \\
\hline $\mathrm{C} 3-\mathrm{C} 4$ & $\pi$ & 1.55498 & $\mathrm{C} 13-\mathrm{N} 14$ & $\pi^{*}$ & 0.21940 & 23.30 & 0.25 & 0.072 \\
\hline C5-C6 & $\pi$ & 1.65905 & $\mathrm{C} 1-\mathrm{C} 2$ & $\pi^{*}$ & 0.27464 & 22.39 & 0.28 & 0.072 \\
\hline $\mathrm{C} 5-\mathrm{C} 6$ & $\pi$ & 1.65905 & $\mathrm{C} 1-\mathrm{C} 2$ & $\pi^{*}$ & 0.45595 & 15.42 & 0.26 & 0.059 \\
\hline C5-C6 & $\pi$ & 1.65905 & $\mathrm{C} 7-\mathrm{O} 8$ & $\pi^{*}$ & 0.28565 & 27.55 & 0.24 & 0.074 \\
\hline $\mathrm{C} 13-\mathrm{C} 14$ & $\pi$ & 1.91336 & $\mathrm{C} 3-\mathrm{C} 4$ & $\pi^{*}$ & 0.45595 & 6.89 & 0.94 & 0.023 \\
\hline $\mathrm{C} 13-\mathrm{C} 14$ & $\pi$ & 1.91336 & $\mathrm{C} 15-\mathrm{C} 16$ & $\pi^{*}$ & 0.44368 & 9.43 & 0.37 & 0.058 \\
\hline $\mathrm{C} 15-\mathrm{C} 16$ & $\pi$ & 1.96604 & C13-N14 & $\pi^{*}$ & 0.21940 & 11.21 & 0.24 & 0.049 \\
\hline $\mathrm{C} 15-\mathrm{C} 16$ & $\pi$ & 1.96604 & C17-C18 & $\pi^{*}$ & 0.46912 & 19.03 & 0.28 & 0.066 \\
\hline C15-C16 & $\pi$ & 1.96604 & C19-C20 & $\pi^{*}$ & 0.32861 & 19.83 & 0.27 & 0.067 \\
\hline $\mathrm{C} 15-\mathrm{C} 16$ & $\pi$ & 1.96604 & $\mathrm{C} 21-\mathrm{C} 22$ & $\pi^{*}$ & 0.18831 & 15.74 & 0.29 & 0.064 \\
\hline C17-C18 & $\pi$ & 1.52506 & $\mathrm{C} 15-\mathrm{C} 16$ & $\pi^{*}$ & 0.44368 & 20.29 & 0.26 & 0.066 \\
\hline C17-C18 & $\pi$ & 1.52506 & $\mathrm{C} 19-\mathrm{C} 20$ & $\pi^{*}$ & 0.32861 & 19.87 & 0.26 & 0.066 \\
\hline C17-C18 & $\pi$ & 1.52506 & $\mathrm{C} 24-\mathrm{C} 25$ & $\pi^{*}$ & 0.46625 & 19.54 & 0.27 & 0.065 \\
\hline C17-C18 & $\pi$ & 1.52506 & C26-C27 & $\pi^{*}$ & 0.19336 & 14.49 & 0.28 & 0.061 \\
\hline $\mathrm{C} 19-\mathrm{C} 20$ & $\pi$ & 1.68814 & $\mathrm{C} 15-\mathrm{C} 16$ & $\pi^{*}$ & 0.44368 & 19.18 & 0.28 & 0.068 \\
\hline $\mathrm{C} 19-\mathrm{C} 20$ & $\pi$ & 1.68814 & C17-C18 & $\pi^{*}$ & 0.46912 & 17.64 & 0.29 & 0.066 \\
\hline C21-C22 & $\pi$ & 1.79067 & $\mathrm{C} 15-\mathrm{C} 16$ & $\pi^{*}$ & 0.44368 & 17.23 & 0.28 & 0.066 \\
\hline C24-C25 & $\pi$ & 1.53004 & C17-C18 & $\pi^{*}$ & 0.46912 & 20.01 & 0.27 & 0.065 \\
\hline C24-C25 & $\pi$ & 1.53004 & $\mathrm{C} 26-\mathrm{C} 27$ & $\pi^{*}$ & 0.19336 & 14.62 & 0.27 & 0.061 \\
\hline $\mathrm{C} 26-\mathrm{C} 27$ & $\pi$ & 1.79745 & C17-C18 & $\pi^{*}$ & 0.46912 & 14.32 & 0.29 & 0.062 \\
\hline C26-C27 & $\pi$ & 1.79745 & C24-C25 & $\pi^{*}$ & 0.46625 & 14.02 & 0.30 & 0.062 \\
\hline $\mathrm{LP}(2) \mathrm{O} 8$ & $n$ & 1.86096 & C6-C7 & $\sigma^{*}$ & 0.05894 & 15.13 & 0.69 & 0.093 \\
\hline $\mathrm{LP}(2) \mathrm{O} 8$ & $n$ & 1.86096 & C7-O9 & $\sigma^{*}$ & 0.10070 & 32.78 & 0.57 & 0.123 \\
\hline LP(1)O9 & $n$ & 1.96939 & $\mathrm{C} 7-\mathrm{O} 8$ & $\sigma^{*}$ & 0.01769 & 6.52 & 1.08 & 0.075 \\
\hline LP(2)O9 & $n$ & 1.80240 & $\mathrm{C} 7-\mathrm{O} 8$ & $\pi^{*}$ & 0.28565 & 46.67 & 0.30 & 0.108 \\
\hline LP(2)O9 & $n$ & 1.80240 & $\mathrm{C} 7-\mathrm{O} 8$ & $\pi^{*}$ & 0.28565 & 46.67 & 0.30 & 0.108 \\
\hline $\mathrm{LP}(1) \mathrm{O} 12$ & $n$ & 1.97419 & C3-C4 & $\sigma$ & 0.04045 & 7.37 & 1.05 & 0.079 \\
\hline $\mathrm{LP}(2) \mathrm{O} 12$ & $n$ & 1.79696 & $\mathrm{C} 3-\mathrm{C} 4$ & $\pi^{*}$ & 0.45595 & 37.12 & 0.31 & 0.102 \\
\hline LP(1)N14 & $n$ & 1.84279 & $\mathrm{C} 3-\mathrm{C} 4$ & $\sigma^{*}$ & 0.03276 & 10.67 & 0.74 & 0.082 \\
\hline $\mathrm{LP}(1) \mathrm{C} 23$ & $n$ & 0.99827 & $\mathrm{C} 21-\mathrm{C} 22$ & $\pi^{*}$ & 0.18831 & 48.68 & 0.14 & 0.097 \\
\hline $\mathrm{LP}(1) \mathrm{C} 23$ & $n$ & 0.99827 & C24-C25 & $\pi^{*}$ & 0.46625 & 71.49 & 0.14 & 0.103 \\
\hline $\mathrm{LP}(1) \mathrm{C} 23$ & $n$ & 0.99827 & $\mathrm{C} 21-\mathrm{C} 22$ & $\pi^{*}$ & 0.33071 & 68.23 & 0.13 & 0.104 \\
\hline
\end{tabular}

${ }^{a} E(2)$ means stabilization energy.

${ }^{\mathrm{b}}$ Energy difference between the donor and acceptor NBO orbitals.

${ }^{\mathrm{c}} F(i, j)$ is the Fock matrix element between $i$ and $j \mathrm{NBO}$ orbitals.

\section{Conclusions}

Using DFT/B3LYP/6-311++G(2d, 2p) level of theory a detailed study of molecular structure, NMR chemical shifts, electronic properties, MEP surface mapping, NBO analysis, and vibrational and PED analysis of the title compound has been investigated and reported. On comparison with experimentally obtained parameters by one of coauthors of this paper we found that both of them are in agreement with each other. HOMO-LUMO analysis of the title compound shows that the electron charge distribution is mainly concentrated over the rings and there may be a charge transfer through $\pi$ system which accounts for bioactivity of the molecule. The title compound has also large band gap as reported in HOMO-LUMO analysis which accounts for its future applications as a useful material in solar cell devices. Molecular electrostatic surface maps give an idea about the chemical reactivity of the title compound. Our overall simulated results for different molecular properties of the title compound are obtained for the first time and we hope that they are helpful in the synthesis and design of new applications. 


\section{Conflict of Interests}

The authors declare that there is no conflict of interests regarding the publication of this paper.

\section{Acknowledgments}

The authors thank Indian Institute of technology Mandi for providing the infrastructure required for computational studies as well MHRD scholarships. The authors also want to thank Dr. C. P. Parameswaran for allowing them to use some of the experimental data for comparison with simulated results along with useful and fruitful discussions for the completion of the paper.

\section{References}

[1] A. K. Gupta, A. Dhir, and C. P. Pradeep, "A fluorescence 'turnon'chemodosimeter for selective detection of $\mathrm{Nb}^{5+}$ ions in mixed aqueous media," Dalton Transactions, vol. 42, no. 36, pp. 12819-12823, 2013.

[2] J. R. Lakowicz, Topics in Fluorescence Spectroscopy. Volume 4: Probe Design and Chemical Sensing, Plenum Press, New York, NY, USA, 1994.

[3] J. L. H. Lindenhovius, E. M. Hornsveld, A. den Ouden, W. A. J. Wessel, and H. H. J. ten Kate, "Powder-in-tube (PIT) Nb3Sn conductors for high-field magnets," IEEE Transactions on Applied Superconductivity, vol. 10, no. 1, pp. 975-978, 2000.

[4] D. Touati, "Iron and oxidative stress in bacteria," Archives of Biochemistry and Biophysics, vol. 373, no. 1, pp. 1-6, 2000.

[5] B. Çatikkaş, E. Aktan, and Z. Seferoğlu, "DFT, FT-Raman, FTIR, NMR, and UV-Vis studies of a hetarylazo indole dye," International Journal of Quantum Chemistry, vol. 113, no. 5, pp. 683-689, 2013.

[6] A. Raj, Y. Sheena Mary, C. Yohannan Panicker, H. T. Varghese, and K. Raju, "IR, Raman, SERS and computational study of 2(benzylsulfanyl)-3,5-dinitrobenzoic acid," Spectrochimica Acta A: Molecular and Biomolecular Spectroscopy, vol. 113, pp. 28-36, 2013.

[7] V. Chiş, S. Filip, V. Miclǎuş et al., "Vibrational spectroscopy and theoretical studies on 2,4- dinitrophenylhydrazine," Journal of Molecular Structure, vol. 744-747, pp. 363-368, 2005.

[8] M. Kumru, V. Küçük, and P. Akyürek, "Vibrational spectra of quinoline-4-carbaldehyde: combined experimental and theoretical studies," Spectrochimica Acta A: Molecular and Bimolecular Spectroscopy, vol. 113, pp. 72-79, 2013.

[9] R. J. Xavier and P. Dinesh, "Conformational stability, vibrational spectra, HOMO-LUMO and NBO analysis of 1,3,4thiadiazolidine-2,5-dithione with experimental (FT-IR and FTRaman) techniques and scaled quantum mechanical calculations," Spectrochimica Acta A: Molecular and Biomolecular Spectroscopy, vol. 113, pp. 171-181, 2013.

[10] C. Lee, W. Yang, and R. G. Parr, "Development of the ColleSalvetti correlation-energy formula into a functional of the electron density," Physical Review B, vol. 37, no. 2, pp. 785-789, 1988.

[11] R. Dltchfield, "Molecular orbital theory of magnetic shielding and magnetic susceptibility," The Journal of Chemical Physics, vol. 56, no. 11, pp. 5688-5691, 1972.

[12] K. Wolinski, J. F. Hinton, and P. Pulay, "Efficient implementation of the gauge-independent atomic orbital method for NMR chemical shift calculations," Journal of the American Chemical Society, vol. 112, no. 23, pp. 8251-8260, 1990.

[13] E. D. Glendening and A. E. Reed, NBO Version 3.1, TCL, University of Wisconsin, Madison, Wis, USA, 1998.

[14] M. Izadyar and M. Khavani, "Quantum chemistry aspects of the solvent effects on the ene reaction of 1-Phenyl-1,3,4-triazolin2,5-dione and 2-methyl-2-butene," International Journal of Quantum Chemistry, vol. 114, no. 10, pp. 666-674, 2014.

[15] H. Pir, N. Günay, Ö. Tamer, D. Avci, and Y. Atalay, "Theoretical investigation of 5-(2-Acetoxyethyl)-6-methylpyrimidin2,4-dione: Conformational study, NBO and NLO analysis, molecular structure and NMR spectra," Spectrochimica Acta A: Molecular and Biomolecular Spectroscopy, vol. 112, pp. 331-342, 2013.

[16] Diwaker, "Quantum mechanical and spectroscopic (FT-IR, ${ }^{13} \mathrm{C}$, ${ }^{1} \mathrm{H}$ NMR and UV) investigations of 2-(5-(4-Chlorophenyl)3-(pyridin-2-yl)-4,5-dihydropyrazol-1-yl)benzo[d]thiazole by DFT method," Spectrochimica Acta A: Molecular and Biomolecular Spectroscopy, vol. 128, pp. 819-829, 2014.

[17] J. Fleming, Frontier Orbitals and Organic Chemical Reactions, John Wiley and Sons, New York, NY, USA, 1981.

[18] R. G. Pearson, "Absolute electronegativity and hardness correlated with molecular orbital theory," Proceedings of the National Academy of Sciences, vol. 83, no. 22, pp. 8440-8441, 1986.

[19] P. Politzer, P. R. Laurence, and K. Jayasuriya, "Molecular electrostatic potentials: an effective tool for the elucidation of biochemical phenomena," Environmental Health Perspectives, vol. 61, pp. 191-202, 1985.

[20] A. Pullman, B. Pullman, and R. Lavery, "Molecular electrostatic potential versus field. significance for DNA and its constituents," Journal of Molecular Structure: THEOCHEM, vol. 93, pp. 85-91, 1983.

[21] V. D. Vitnik, J. Ž. Vitnik, N. R. Banjac, N. V. Valentić, G. S. Ušćumlić, and I. O. Juranić, "Quantum mechanical and spectroscopic (FT-IR, ${ }^{13} \mathrm{C},{ }^{1} \mathrm{H}$ NMR and UV) investigations of potent antiepileptic drug 1-(4-chloro-phenyl)-3phenyl-succinimide," Spectrochimica Acta A: Molecular and Biomolecular Spectroscopy, vol. 117, pp. 42-53, 2014.

[22] B. Çatıkkaş, E. Aktan, and Z. Seferoğlu, "DFT, FT-Raman, FTIR, NMR, and UV-Vis studies of a hetarylazo indole dye," International Journal of Quantum Chemistry, vol. 113, no. 5, pp. 683-689, 2013.

[23] M. H. Jamróz, J. C. Dobrowolski, and R. Brzozowski, "Vibrational modes of 2,6-, 2,7-, and 2,3-diisopropylnaphthalene. A DFT study," Journal of Molecular Structure, vol. 787, no. 1-3, pp. 172-183, 2006.

[24] Gaussian 09, “Gaussian,” Wallingford CT, 2004.

[25] N. Günay, H. Pir, D. Avci, and Y. Atalay, "NLO and NBO analysis of Sarcosine-Maleic acid by using HF and B3LYP calculations," Journal of Chemistry, vol. 2013, Article ID 712130, 16 pages, 2013.

[26] W. B. Person and J. H. Newton, "Dipole moment derivatives and infrared intensities. I. Polar tensors," The Journal of Chemical Physics, vol. 61, no. 3, pp. 1040-1049, 1974. 

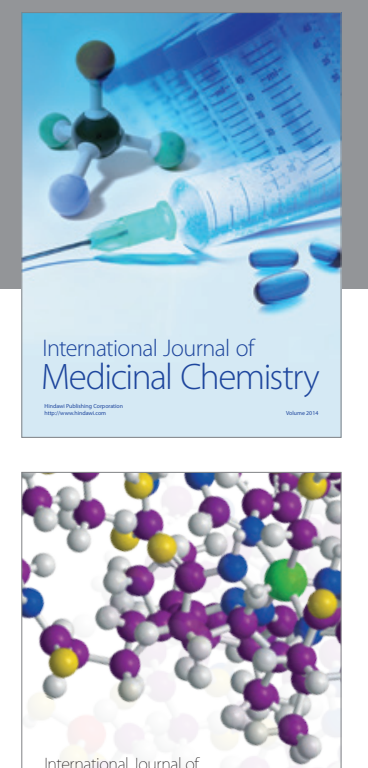

\section{Carbohydrate} Chemistry

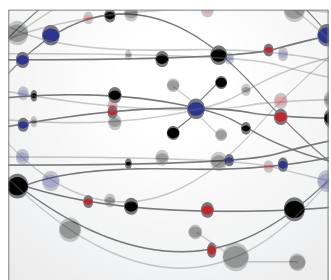

The Scientific World Journal
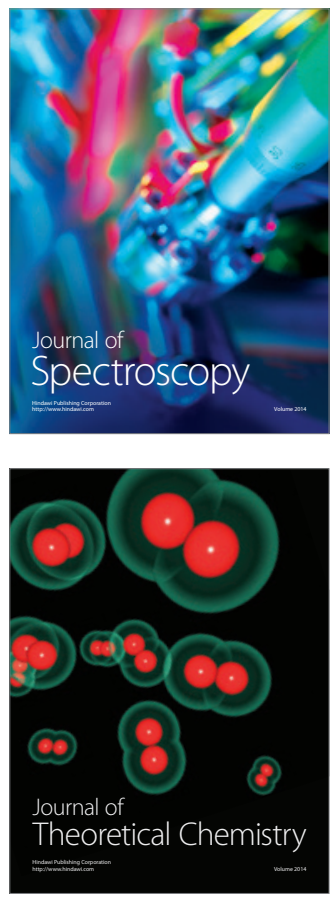
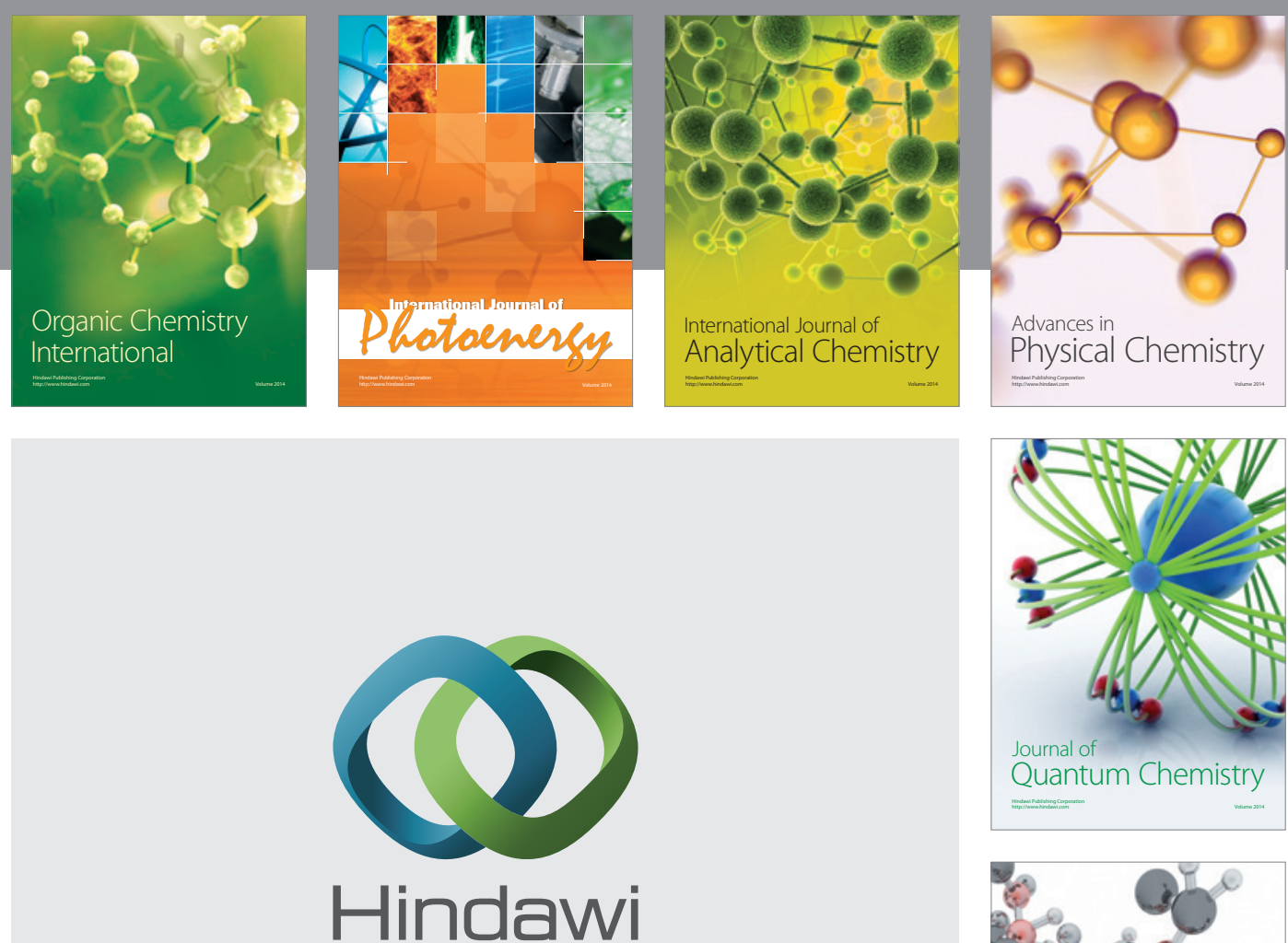

Submit your manuscripts at

http://www.hindawi.com

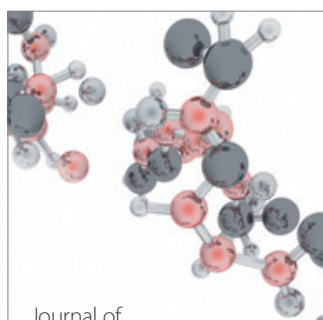

Analytical Methods

in Chemistry

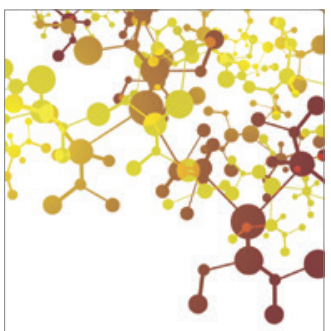

Journal of

Applied Chemistry

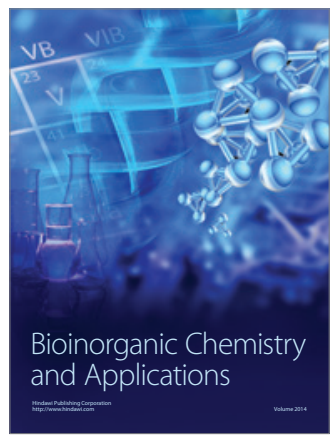

Inorganic Chemistry
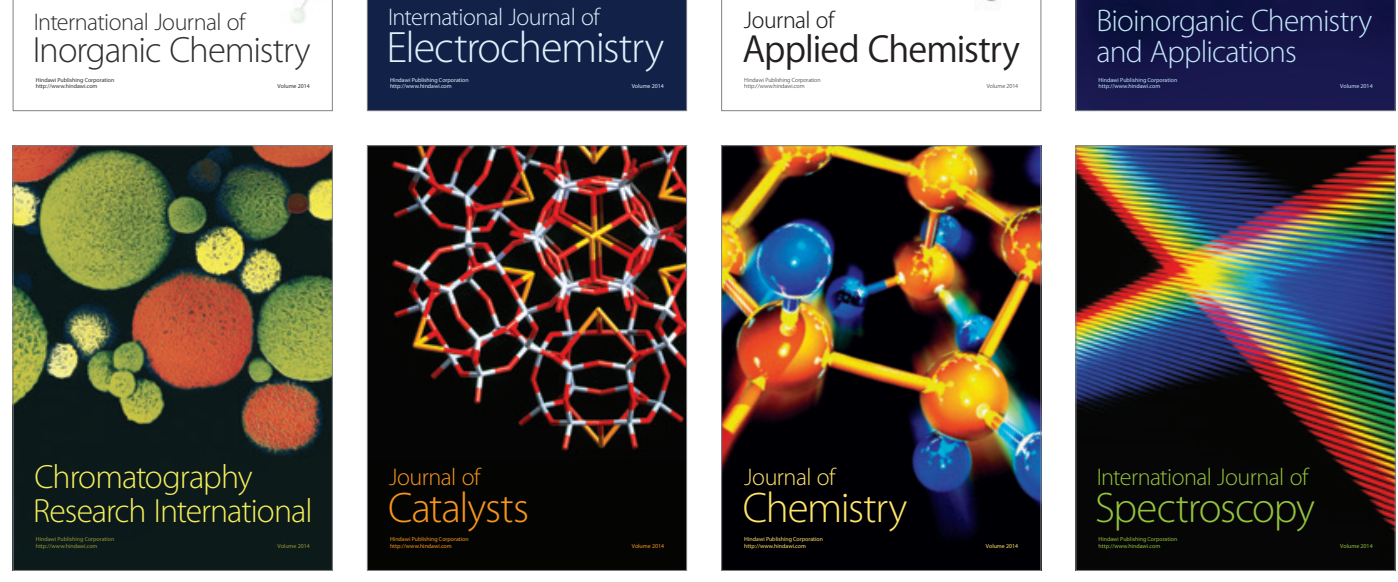